\title{
Total Chemical Synthesis of All SUMO-2/3 Dimer Combinations
}

Jennifer Bouchenna, Magalie Sénéchal, Hervé Drobecq, Jérôme Vicogne, ${ }^{*}$ Oleg Melnyk*

University of Lille, CNRS, Institut Pasteur de Lille, INSERM U1019, UMR CNRS 8204, Centre d'Immunité et d'Infection de Lille, F-59000 Lille, France.

email of corresponding author:

oleg.melnyk@ibl.cnrs.fr

Jerome.vicogne@ibl.cnrs.fr 


\section{Table of content}

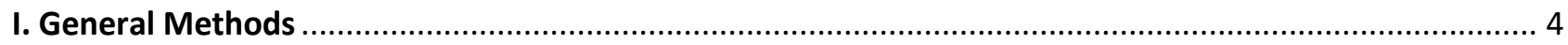

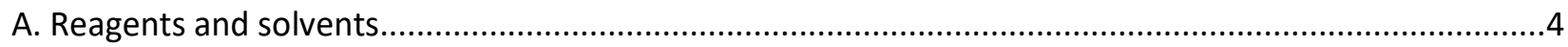

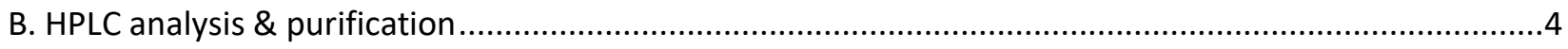

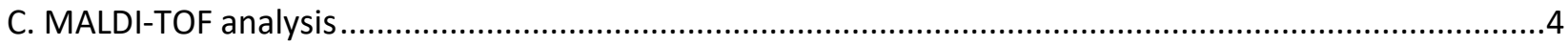

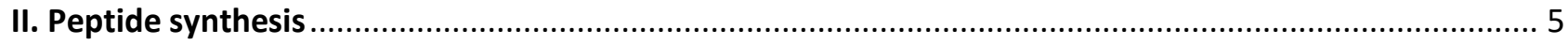

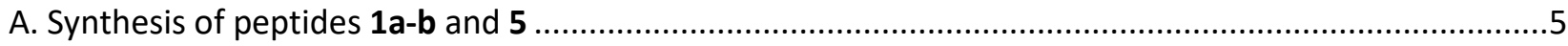

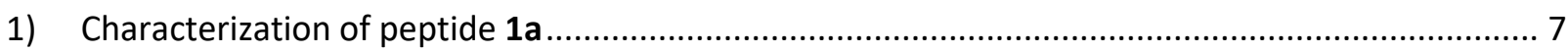

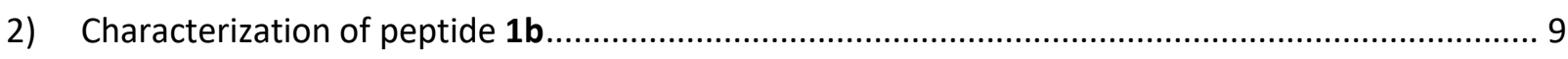

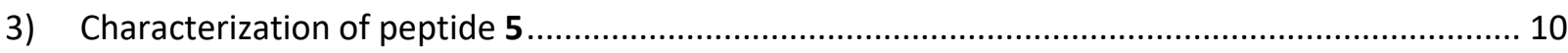

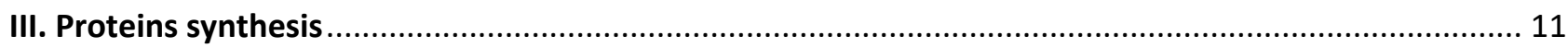

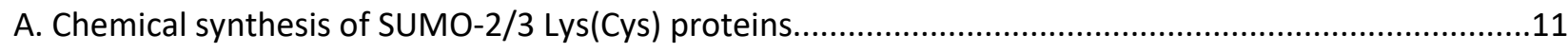

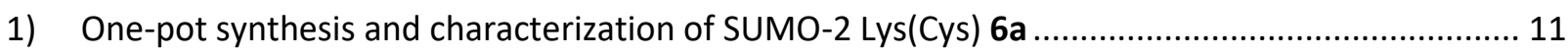

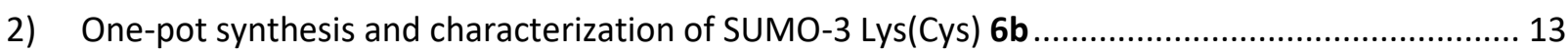

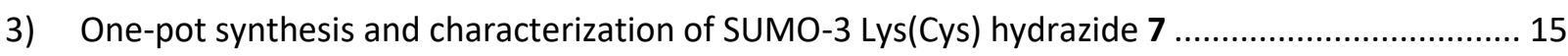

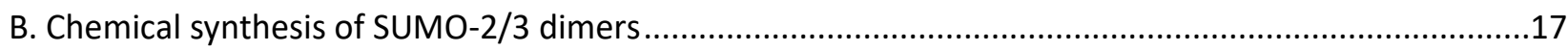

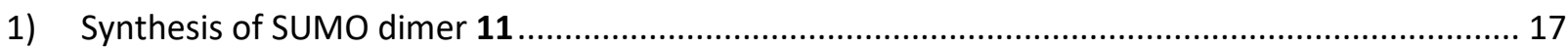

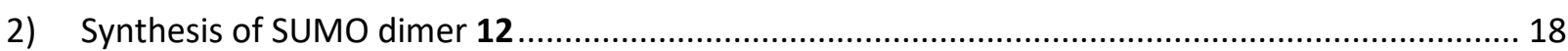

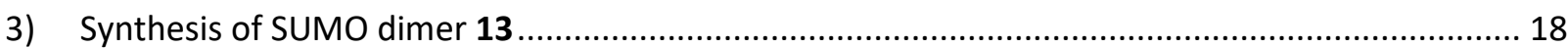

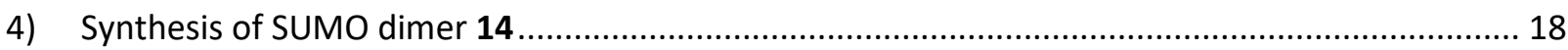

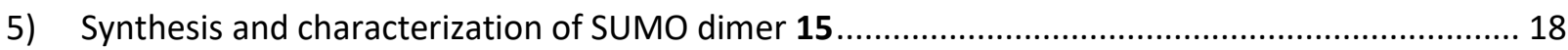

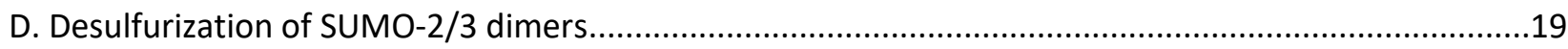

- Desulfurization of SUMO-2/3 dimer 13 in denaturing conditions ............................................... 19

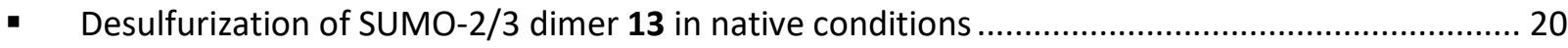

C. Characterization of SUMO-2/3 dimers by proteomics analysis ..........................................................29

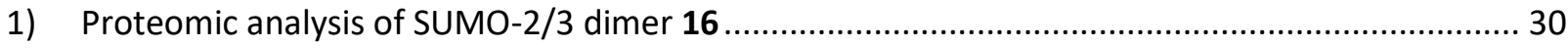

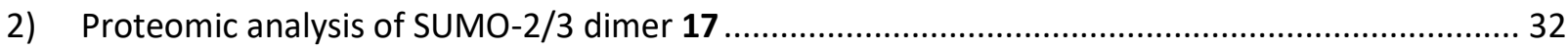

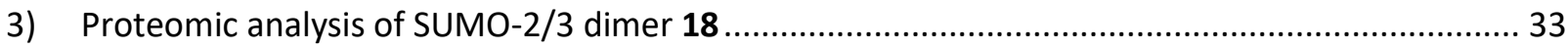

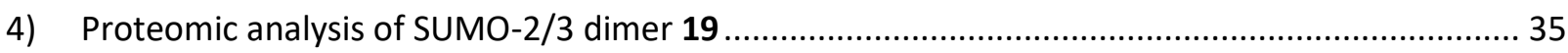

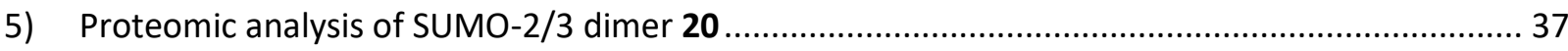

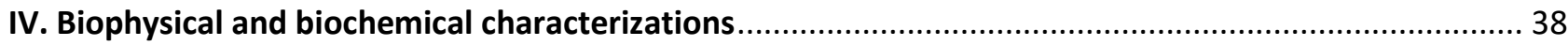

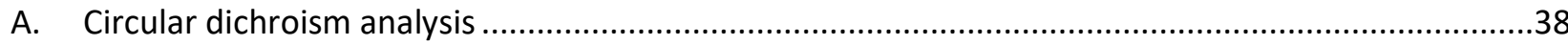

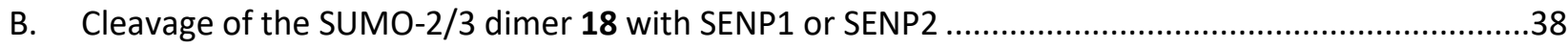

- Monitoring by SDS-PAGE and Coomassie staining (Figure 6) ....................................................... 38

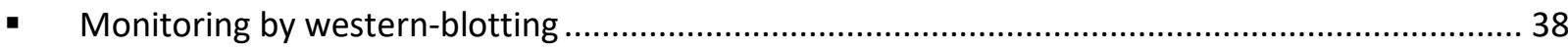


VI. References

39 


\section{General Methods}

\section{A. Reagents and solvents}

$N$-[(dimethylamino)-1H-1,2,3-triazolo-[4,5-b]pyridin-1-ylmethylene]- $N$

methylmethanaminium hexafluorophosphate $\mathrm{N}$-oxide (HATU) and $\mathrm{N \alpha}$-Fmoc protected amino acids were obtained from Iris Biotech $\mathrm{GmbH}$. Side-chain protecting groups used for the amino acids were Fmoc-Ala-OH, Fmoc-Arg(Pbf)-OH, FmocAsn(Trt)-OH, Fmoc-Asp(OtBu)-OH, Fmoc-Asp(OtBu)[Dmb-Gly]-OH, Fmoc-Gln(Trt)-OH, Fmoc-Glu(OtBu)-OH, Fmoc-Gly-OH, Fmoc-His(Trt)-OH, Fmoc-lle-OH, Fmoc-Leu-OH, Fmoc-Lys(Boc)-OH, Fmoc-Met-OH, Fmoc-Phe$\mathrm{OH}$, Fmoc-Pro-OH, Fmoc-Ser(OtBu)-OH, Fmoc-Thr(OtBu)-OH, Fmoc-Tyr(OtBu)-OH, Fmoc-Val-OH, Fmoc$\mathrm{Cys}(\mathrm{StBu})-\mathrm{OH}$ or Fmoc-Cys(Trt)-OH.

Synthesis of bis(2-sulfanylethyl)aminotrityl polystyrene (SEA PS) resin was carried out as described elsewhere. ${ }^{1,2}$ 4-mercaptophenylacetic acid (MPAA) and tris(2-carboxyethyl)phosphine hydrochloride (TCEP) were purchased from Sigma-Aldrich. All other reagents were purchased from Acros Organics or Merck and were of the purest grade available. Peptide synthesis grade $\mathrm{N}, \mathrm{N}$-dimethylformamide (DMF), dichloromethane $\left(\mathrm{CH}_{2} \mathrm{Cl}_{2}\right)$, diethylether $\left(\mathrm{Et}_{2} \mathrm{O}\right)$, acetonitrile $\left(\mathrm{CH}_{3} \mathrm{CN}\right)$, heptane, LC-MS-grade acetonitrile $\left(\mathrm{CH}_{3} \mathrm{CN}, 0.1 \%\right.$ TFA and $\mathrm{CH}_{3} \mathrm{CN}, 0.1 \%$ formic acid), LC-MS-grade water $\left(\mathrm{H}_{2} \mathrm{O}, 0.1 \%\right.$ TFA and $\mathrm{H}_{2} \mathrm{O}, 0.1 \%$ formic acid), $\mathrm{N}, \mathrm{N}$-diisopropylethylamine (DIEA), acetic anhydride $\left(\mathrm{Ac}_{2} \mathrm{O}\right)$ were purchased from Biosolve and FisherChemical. Trifluoroacetic acid (TFA) was obtained from Biosolve. Water was purified with a Milli-Q Ultra Pure Water Purification System.

\section{B. HPLC analysis \& purification}

The reactions were monitored by analytical UPLC-MS (Dionex UltiMate 3000 LC/ LCQ Fleet lon Trap) on a reverse phase column. The column, eluent system and gradient used are indicated in the figure legends. The column eluate was monitored with a Dionex DA detector $(215 \mathrm{~nm}, 254 \mathrm{~nm})$ and Corona Veo charged aerosol detector. The peptide masses were measured by on-line UPLC-MS: lonization mode: ES+, m/z range 3002000 , capillary voltage $3.5 \mathrm{kV}$, cone voltage $10 \mathrm{~V}$, tube lens $75 \mathrm{~V}$, capillary voltage temperature $350^{\circ} \mathrm{C}$. Ligations were analyzed by quenching aliquots $(1.5-2 \mu \mathrm{L})$ of the reaction mixtures with $100 \mu \mathrm{L}$ of $10 \%$ aqueous acetic acid. The mixture was extracted with $\mathrm{Et}_{2} \mathrm{O}$ to remove MPAA before analysis.

The peptides were purified by semi-preparative HPLC (Waters 600 controller, UV 2487 Detector, $215 \mathrm{~nm}$, TL 105 HPLC column heater) on a reverse phase column (Waters XBridge BEH300 C18, $20 \times 100 \mathrm{~mm}$; pore size $300 \AA$; particle size : $5 \mu \mathrm{m}$ ). The eluent system and gradient used are indicated in the figure legends.

\section{MALDI-TOF analysis}

MALDI-TOF mass spectra were recorded with a BrukerAutoflex Speed mass spectrometer. The matrix used for the analysis is indicated in the figure legends. 


\section{Peptide synthesis}

Peptides 4, 8a-b and $\mathbf{9}$ were produced as described elsewhere. ${ }^{3}$

\section{A. Synthesis of peptides $1 a-b$ and 5}

Peptide 1a: ADEKPKEGVK(C)TENNDHINLKVAGQDGSVVQFKIKRHTPLSKLMKAY-SEA ${ }^{\text {on }}$

Peptide 1b: SEEKPKEGVK(C)TENDHINLKVAGQDGSVVQFKIKRHTPLSKLMKAY-SEA ${ }^{\text {on }}$

Peptide 5: CERQGLSMRQIRFRFDGQPINETDTPAQLEMEDEDTIDVFQQQTGG-NHNH ${ }_{2}$

\section{Coupling of the first amino acid residue to the SEA ChemMatrix resin}

The first amino acid was coupled manually to the SEA ChemMatrix ${ }^{\circledR}$ resin for SEA peptides (Scheme S 1) or to the HMPA ChemMatrix ${ }^{\circledR}$ resin for peptide acids using HATU/DIEA activation in DMF.

Scheme S 1. Loading of the first amino acid on the resin. Loading on SEA ChemMatrix $₫$ resin

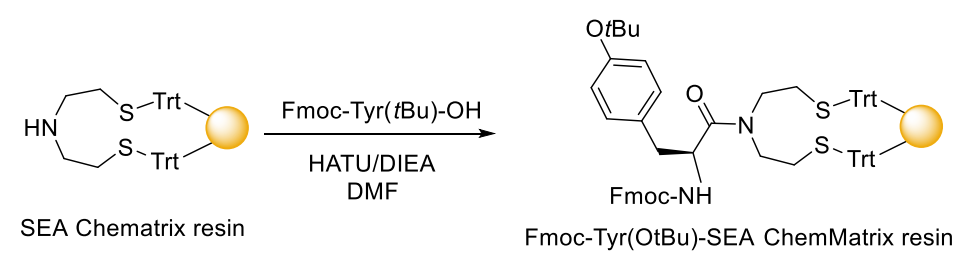

SEA ChemMatrix resin $(0.220 \mathrm{mmol} / \mathrm{g}, 454 \mathrm{mg}, 100 \mu \mathrm{mol})$ was conditioned in $\mathrm{CH}_{2} \mathrm{Cl}_{2}(3 \times 2 \mathrm{~min}, 3 \mathrm{~mL})$ and then in DMF $(3 \times 2 \mathrm{~min}, 3 \mathrm{~mL})$ in a manual SPPS glass reactor.

Fmoc-Tyr(OtBu)-OH (460 mg, $1.00 \mathrm{mmol})$ and HATU (376 mg, $0.950 \mathrm{mmol})$ were dissolved in the minimal volume of DMF ( $2 \mathrm{~mL}$ ). DIEA ( $348 \mu \mathrm{L}, 2.00 \mathrm{mmol}$ ) was added to the above solution to start the activation of the amino acid. This solution was agitated for $1 \mathrm{~min}$ and then added to the resin which was shaken during 1 h $30 \mathrm{~min}$ at room temperature. The resin was subsequently washed with DMF ( $5 \times 2 \mathrm{~min}, 3 \mathrm{~mL})$. The chloranil assay was negative. The resin was then acetylated with a mixture of acetic anhydride/DIEA/DMF: 10/5/85 by vol $(2 \times 3 \mathrm{~mL}, 2 \mathrm{~min}$ and then $20 \mathrm{~min})$ before being washed successively with DMF $(3 \times 2 \mathrm{~min}, 3 \mathrm{~mL}), \mathrm{CH}_{2} \mathrm{Cl}_{2}$ $(3 \times 2 \mathrm{~min}, 3 \mathrm{~mL})$ and diethylether $(3 \times 2 \mathrm{~min}, 3 \mathrm{~mL})$. The resin was finally dried in vacuo for $\sim 2 \mathrm{~h}$.

\section{Preparation of hydrazine PS resin}

Commercial 2-chloro-4'-polystyryl triphenylmethyl chloride resin $(0.600 \mathrm{mmol} / \mathrm{g}, 667 \mathrm{mg}, 400 \mu \mathrm{mol})$ was swollen for $15 \mathrm{~min}$ in DMF ( $150 \mathrm{~mL}$ ) and cooled at $0{ }^{\circ} \mathrm{C}$. A mixture of trimethylamine ( $6 \mathrm{eq}, 240 \mathrm{mmole}, 334.5$ $\mu \mathrm{L}$ ) and hydrazine hydrate (4 eq, $160 \mathrm{mmole}, 102.4 \mu \mathrm{L}$ ) in DMF $(4 \mathrm{~mL})$ was added dropwise and the suspension was stirred for $60 \mathrm{~min}$ at room temperature. Methanol $(107 \mu \mathrm{L})$ was then added and stirring continued for $10 \mathrm{~min}$ in order to quench the excess of reactive $\mathrm{Cl}$. The resin was filtered, washed with DMF $(2 \times 5 \mathrm{~mL})$, water $(2 \times 5 \mathrm{~mL})$, DMF $(2 \times 5 \mathrm{~mL})$, methanol $(2 \times 5 \mathrm{~mL})$ and ether and dried in vacuo for $2 \mathrm{~h}$ at room temperature (protocol adapted from ref ${ }^{4}$ ).

Coupling of the first amino acid residue to the hydrazide PS resin 
Fmoc-Gly-OH (297 mg, $1.00 \mathrm{mmol})$ and HATU $(376 \mathrm{mg}, 0.950 \mathrm{mmol})$ were dissolved in the minimal volume of DMF ( $2 \mathrm{~mL}$ ). DIEA ( $348 \mu \mathrm{L}, 2.00 \mathrm{mmol}$ ) was added to the above solution to start the activation of the amino acid. This solution was agitated for $1 \mathrm{~min}$ and then added to the hydrazine resin prepared above ( 1.00 mmole) which was shaken during $1 \mathrm{~h} 30 \mathrm{~min}$ at room temperature. The resin was subsequently washed with DMF $(5 \times 2 \mathrm{~min}, 3 \mathrm{~mL})$. The picrylsulfonic acid assay was negative. The resin was then acetylated with a mixture of acetic anhydride/DIEA/DMF: 10/5/85 by vol $(2 \times 3 \mathrm{~mL}, 2 \mathrm{~min}$ and then $20 \mathrm{~min})$ before being washed successively with DMF $(3 \times 2 \mathrm{~min}, 3 \mathrm{~mL}), \mathrm{CH}_{2} \mathrm{Cl}_{2}(3 \times 2 \mathrm{~min}, 3 \mathrm{~mL})$ and diethylether $(3 \times 2 \mathrm{~min}, 3 \mathrm{~mL})$. The resin was finally dried in vacuo for $\sim 2 \mathrm{~h}$.

\section{Determination of resin loading}

The loading of the resins was determined by UV quantification at $290 \mathrm{~nm}$ of the dibenzofulvene-piperidine adduct formed by treating aliquots of the resin with piperidine ( $20 \%$ by vol in DMF). We found $0.18 \mathrm{mmol} / \mathrm{g}$ for Fmoc-Tyr(OtBu)-SEA ChemMatrix resin and $0.18 \mathrm{mmol} / \mathrm{g}$ for Fmoc-Gly-hydrazine PS resin.

\section{Automated solid phase peptide synthesis}

The peptide elongation step was performed using an automated column peptide synthesizer and standard Fmoc-SPPS protocols $(0.1 \mathrm{mmol}$ scale). The amino acids (10 equiv) were activated using HATU (9.9 equiv)/DIEA (20 equiv) in DMF. The peptidyl resin was acetylated with $\mathrm{Ac}_{2} \mathrm{O} / \mathrm{DIEA} / \mathrm{DMF} 10 / 5 / 85$ by vol after each coupling step.

\section{Coupling of the dipeptide unit Fmoc-Asp(OtBu)-(Dmb)Gly-OH}

Fmoc-Asp(OtBu)-(Dmb)Gly-OH (186 mg, $0.300 \mathrm{mmol}, 3$ equiv) and HATU (108 mg, 0.284 mmol, 2.85 equiv) were dissolved in the minimal volume of DMF ( $2 \mathrm{~mL}$ ). DIEA (104 $\mu \mathrm{L}, 0.600 \mathrm{mmol}, 6$ equiv) was added to the above solution to start the activation of the amino acid. This solution was agitated for $1 \mathrm{~min}$ and then added to the resin which was shaken for $1 \mathrm{~h} 30 \mathrm{~min}$ at room temperature. The resin was subsequently washed with $\operatorname{DMF}(5 \times 2 \mathrm{~min}, 3 \mathrm{~mL})$.

The chloranil assay was negative. An aliquot of the peptidyl resin was treated with piperidine in DMF (20\% by vol) and cleaved for $1 \mathrm{~h} 30 \mathrm{~min}$ in a mixture of TFA/triisopropylsilane (TIS)//thioanisole/ $\mathrm{H}_{2} \mathrm{O} /$ thiophenol: $87.5 / 5 / 2.5 / 2.5 / 2.5$ by vol $(1 \mathrm{~mL})$ for SEA ChemMatrix ${ }^{\circledR}$ resin, or TFA/TIS/ $\mathrm{H}_{2} \mathrm{O} /$ ethanedithiol (EDT): $90 / 5 / 2.5 / 2.5$ by vol ( $1 \mathrm{~mL}$ ) for hydrazide PS resin $1 \mu \mathrm{L}$ of the cleavage mixture was diluted with water $(50 \mu \mathrm{L})$ and analyzed by MALDI-TOF to confirm the successful coupling of the dipeptide unit.

\section{Deprotection and cleavage step}

The peptidyl resins $(0.1 \mathrm{mmol}$ scale) were deprotected and cleaved in a mixture of TFA/TIS/thioanisole/ $\mathrm{H}_{2} \mathrm{O} /$ thiophenol: $87.5 / 5 / 2.5 / 2.5 / 2.5$ by vol $(10 \mathrm{~mL}$ ) for $1 \mathrm{~h} 30 \mathrm{~min}$ (twice) for peptides 1a-b and in a mixture of TFA/TIS/EDT/ $\mathrm{H}_{2} \mathrm{O}: 90 / 5 / 2.5 / 2.5$ by vol $(10 \mathrm{~mL}$ ) for $1 \mathrm{~h} 30 \mathrm{~min}$ (twice) for peptide $\mathbf{5}$. The crude peptides were precipitated in an ice-cold mixture of $\mathrm{Et}_{2} \mathrm{O} / n$-heptane $: 1 / 1$ by vol $(200 \mathrm{~mL})$ to give $280.5 \mathrm{mg}$ ( $53 \%$ crude) of peptide 1a, $276.8 \mathrm{mg}$ ( $51 \%$ crude) of peptide $\mathbf{1 b}, 197.1 \mathrm{mg}$ ( $37 \%$ crude) peptide 5. 
Purification of SEA off peptide segments

The crude peptide segments $\mathbf{1} \mathbf{a}-\mathbf{b}, \mathbf{5}$ were dissolved in phosphate buffer/6 $\mathrm{M}$ guanidine hydrochloride (final peptide concentration $\sim 0.25 \mathrm{mM}$ ). The mixture was then immediately filtered and purified by reversedphase HPLC.

Gradient used for the HPLC purification: eluent A water containing $0.1 \%$ of TFA, eluent $\mathrm{B} \mathrm{CH}_{3} \mathrm{CN} /$ water : $4 / 1$ by vol containing $0.1 \%$ of TFA, gradient: $0-25 \%$ B in $5 \mathrm{~min}$, then $25-45 \%$ B in $50 \mathrm{~min}$, flow rate $6 \mathrm{~mL} / \mathrm{min}, 65$ ${ }^{\circ} \mathrm{C}$, UV detection at $215 \mathrm{~nm}$.

Yield for peptide 1a: $34.4 \mathrm{mg}$ of crude product furnished (11.2 mg, 17\% global yield) of peptide 1a.

Gradient used for the HPLC purification: eluent A water containing $0.1 \%$ of TFA, eluent $\mathrm{B} \mathrm{CH}_{3} \mathrm{CN} /$ water : $4 / 1$ by vol containing $0.1 \%$ of TFA, gradient: $0-25 \%$ B in $5 \mathrm{~min}$, then $25-45 \%$ B in $50 \mathrm{~min}$, flow rate $6 \mathrm{~mL} / \mathrm{min}, 65$ ${ }^{\circ} \mathrm{C}$, UV detection at $215 \mathrm{~nm}$.

Yield for peptide $\mathbf{1 b}$ : $30.8 \mathrm{mg}$ of crude product furnished (11.2 mg, $18 \%$ global yield) of peptide $\mathbf{1} \mathbf{b}$.

Gradient used for the HPLC purification: eluent $\mathrm{C}$ water containing $0.1 \%$ of $\mathrm{FA}$, eluent $\mathrm{D} \mathrm{CH}_{3} \mathrm{CN} /$ water : $4 / 1$ by vol containing $0.1 \%$ of $F A$, gradient: $0-10 \% \mathrm{D}$ in $10 \mathrm{~min}$, then $10-30 \% \mathrm{D}$ in $50 \mathrm{~min}$, flow rate $6 \mathrm{~mL} / \mathrm{min}, 50$ ${ }^{\circ} \mathrm{C}$, UV detection at $215 \mathrm{~nm}$, ZORBAX 300SB-C3 ( $5 \mu \mathrm{m}, 9.4 \times 250 \mathrm{~mm}$ ).

Yield for peptide 5: $36.3 \mathrm{mg}$ of crude product furnished (6.2 $\mathrm{mg}, 6.3 \%$ global yield) of peptide 5 .

\section{1) Characterization of peptide $1 a$}



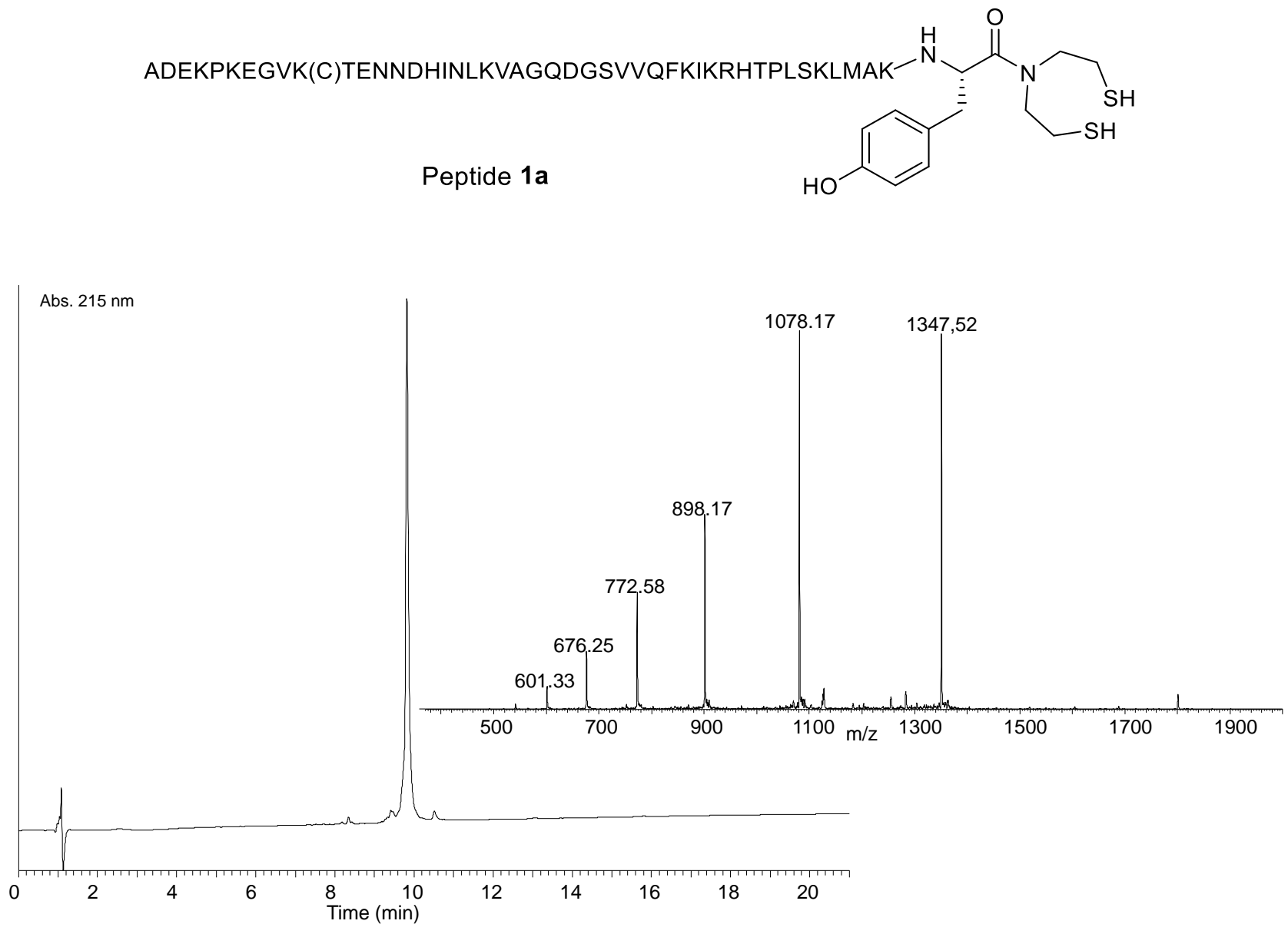

Figure $\mathbf{S} 1$ Analysis of peptide 1a. UPLC-MS analysis ACQUITY UPLC peptide BEH C18 $300 \AA 1.7 \mu \mathrm{m} 2.1 \mathrm{~mm} \times$ $150 \mathrm{~mm}, 50{ }^{\circ} \mathrm{C}$. Flow $0.400 \mathrm{~mL} / \mathrm{min}$, eluent $A 0.1 \%$ trifluoroacetic acid in water, eluent $B 0.1 \%$ trifluoroacetic acid in $100 \%$ acetonitrile. Gradient from $0 \%$ eluent B to $70 \%$ eluent B in $20 \mathrm{~min}$. HPLC trace (UV detection) and MS trace. Calculated for M (average mass) 5386.33, observed 5385.97 after deconvolution. 
2) Characterization of peptide $1 \mathrm{~b}$
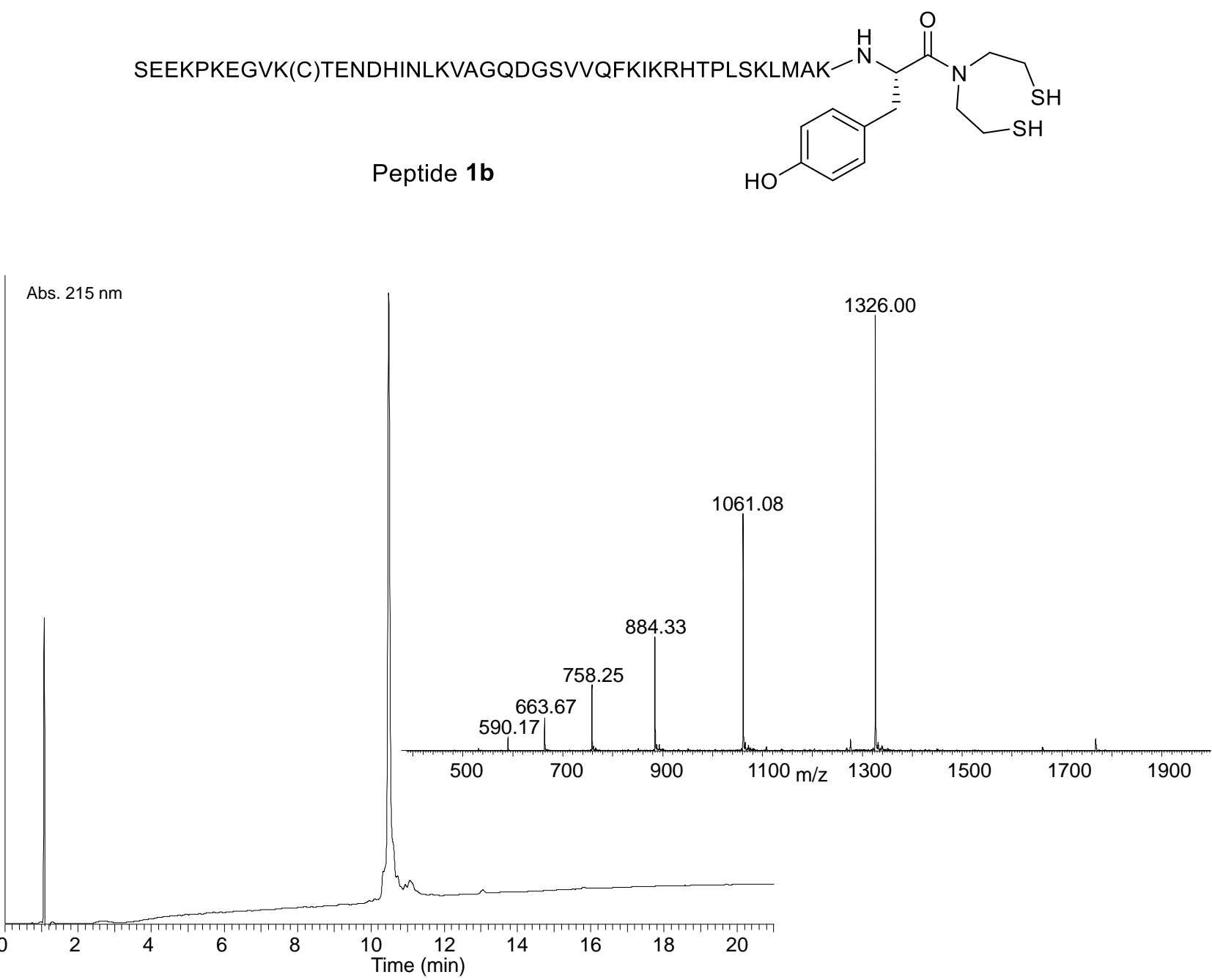

Figure S 2 Analysis of peptide 1b. UPLC-MS analysis ACQUITY UPLC peptide BEH C18 $300 \AA \AA 1.7 \mu \mathrm{m} 2.1 \mathrm{~mm} \times$ $150 \mathrm{~mm}, 50^{\circ} \mathrm{C}$. Flow $0.400 \mathrm{~mL} / \mathrm{min}$, eluent $A 0.1 \%$ trifluoroacetic acid in water, eluent $B 0.1 \%$ trifluoroacetic acid in $100 \%$ acetonitrile. Gradient from $0 \%$ eluent B to $70 \%$ eluent B in 20 min. HPLC trace (UV detection) and MS trace. Calculated for M (average mass) 5302.25 , observed 5302.20 after deconvolution. 
3) Characterization of peptide 5

CERQGLSMRQIRFRFDGQPINETDTPAGLEMEDEDTIDVFQQQTGG-NHNH $\mathrm{N}_{2}$

Peptide 5

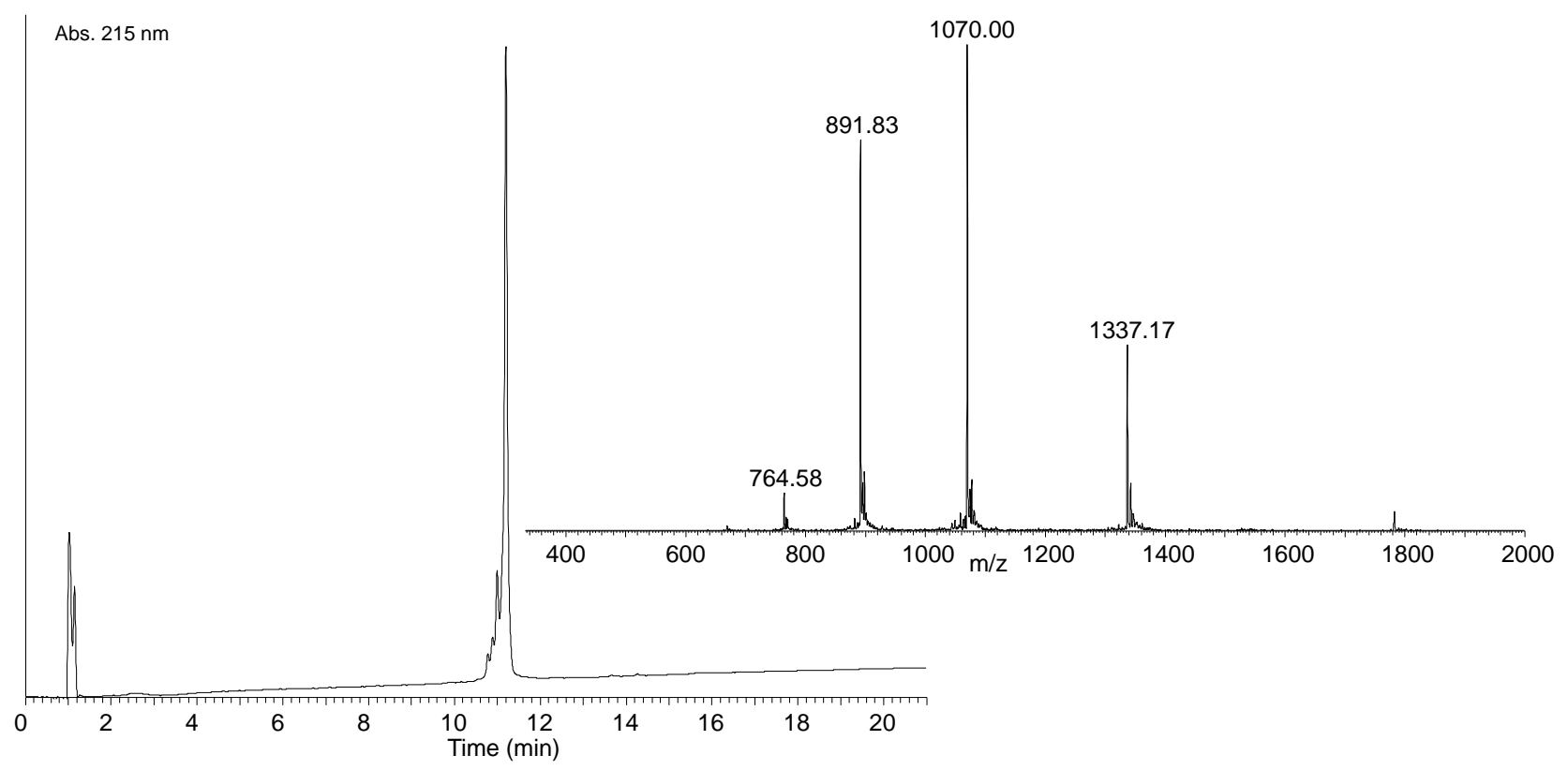

Figure S 3. Analysis of peptide 5. UPLC-MS analysis ACQUITY UPLC peptide BEH C18 $300 \AA 1.7 \mu \mathrm{m} 2.1 \mathrm{~mm} \times$ $150 \mathrm{~mm}, 50^{\circ} \mathrm{C}$. Flow $0.400 \mathrm{~mL} / \mathrm{min}$, eluent $A 0.1 \%$ trifluoroacetic acid in water, eluent $B 0.1 \%$ trifluoroacetic acid in $100 \%$ acetonitrile. Gradient from $0 \%$ eluent B to $70 \%$ eluent B in 20 min. HPLC trace (UV detection) and MS trace. Calculated for M (average mass) 5345.85 , observed 5344.85 after deconvolution. 


\section{Proteins synthesis}

\section{A. Chemical synthesis of SUMO-2/3 Lys(Cys) proteins}

A typical procedure is illustrated with the preparation of peptide $\mathbf{6} \mathbf{a}$.

1) One-pot synthesis and characterization of SUMO-2 Lys(Cys) $6 a$

Oxidation of SEA dithiol into SEA cyclic disulfide

A solution of $\mathrm{N}$-octylglucoside $(6.90 \mathrm{mg}, 20 \mathrm{mM})$ in $6 \mathrm{M}$ guanidinium chloride/ $0.1 \mathrm{M} \mathrm{pH} 7.0$ sodium phosphate buffer $(1.180 \mathrm{~mL})$ was prepared (solution A). Solution $A(501 \mu L)$ was then used to dissolve 4mercaptophenylacetic acid (MPAA, $16.85 \mathrm{mg}, 200 \mathrm{mM}$ ) to give solution B. Then 4-mercaptophenylacetic acid disulfide (MPAA ox, $0.183 \mathrm{mg}, 5 \mathrm{mM}$ ) was dissolved in solution $\mathrm{B}(109 \mu \mathrm{L})$ and the $\mathrm{pH}$ was adjusted to 7.2 by addition of aqueous $\mathrm{NaOH} 6 \mathrm{~N}$ to give solution C. Peptide $1 \mathrm{a}(2.45 \mathrm{mg}, 0.364 \mu \mathrm{mol}, 5 \mathrm{mM})$ was solubilized in solution $\mathrm{C}(72 \mu \mathrm{L})$ and the mixture was stirred for $60 \mathrm{~min}$ to give peptide $\mathbf{2 a}$.

Protection of Lys(Cys) with AcA

Protection of Lys(Cys) residue was performed by adding acetoacetyl-methylthioglycolate (AcA-MTG, 1.00 eq, $0.364 \mu \mathrm{mol}, 7 \mu \mathrm{L}$ of a $10 \mathrm{mg} / \mathrm{mL}$ solution in $6 \mathrm{M}$ guanidinium chloride $/ 0.1 \mathrm{M} \mathrm{pH} 7.0$ sodium phosphate buffer) to the above peptide solution. The reaction was shaken for $23 \mathrm{~h}$ to give solution $\mathrm{D}$.

Ligation

TCEP $(29.02 \mathrm{mg}, 101.2 \mu \mathrm{mol})$ and MPAA $(16.43 \mathrm{mg}, 97.68 \mu \mathrm{mol})$ were dissolved in $6 \mathrm{M}$ guanidinium chloride/0.1 M pH 7.0 sodium phosphate buffer (506 $\mu \mathrm{L})$. Peptide 4 ( $2.14 \mathrm{mg}, 0.364 \mu \mathrm{mol}, 20 \mathrm{mM}$ ) was dissolved in the TCEP/MPAA solution $(68 \mu \mathrm{L})$ and the $\mathrm{pH}$ of was adjusted to 5.5 . Then, this solution was added to solution $\mathrm{D}$. The $\mathrm{pH}$ of the resulting mixture was adjusted again to 5.5 by addition of aqueous $\mathrm{NaOH} 6 \mathrm{~N} \mathrm{(3}$ $\mu \mathrm{L}$ ).The final peptide concentration was $2.1 \mathrm{mM}$. The reaction was shaken for $90 \mathrm{~h}$ to give solution $\mathrm{E}$.

AcA removal

To remove AcA protecting group, a $10 \mathrm{mg} / \mathrm{mL}$ hydroxylamine hydrochloride $\left(\mathrm{NH}_{2} \mathrm{OH} . \mathrm{HCl}\right)$ solution in $6 \mathrm{M}$ guanidinium chloride/ $0.1 \mathrm{M} \mathrm{pH} 7.0$ sodium phosphate buffer was prepared. The solution is acidic due to the presence of $\mathrm{NH}_{2} \mathrm{OH} . \mathrm{HCl}$. This solution $(0.73 \mu \mathrm{mol}, 2.0 \mathrm{eq}, 5.0 \mu \mathrm{L})$ was added to solution $\mathrm{E}$. The deprotection reaction was achieved in $30 \mathrm{~min}$.

\section{Purification}

The crude mixture was purified by semi-preparative HPLC using XBridge BEH300 C18 column $(5 \mu \mathrm{m}, 300 \AA$, $10 \times 250 \mathrm{~mm}$ ), eluent $A$ water containing $0.1 \%$ of TFA, eluent $B \mathrm{CH}_{3} \mathrm{CN} /$ water : $4 / 1$ by vol containing $0.1 \%$ of TFA, gradient: $0-25 \% \mathrm{~B}$ in $5 \mathrm{~min}, 25-45 \% \mathrm{~B}$ in $50 \mathrm{~min}$, flow rate $6 \mathrm{~mL} / \mathrm{min}$, UV detection at $215 \mathrm{~nm}, 65^{\circ} \mathrm{C}$ to give $6 a(1.58 \mathrm{mg}, 60 \%$ overall isolated). 


\section{RFDGQPINETDTPAQLEMEDEDTIDVFQQQTGG}

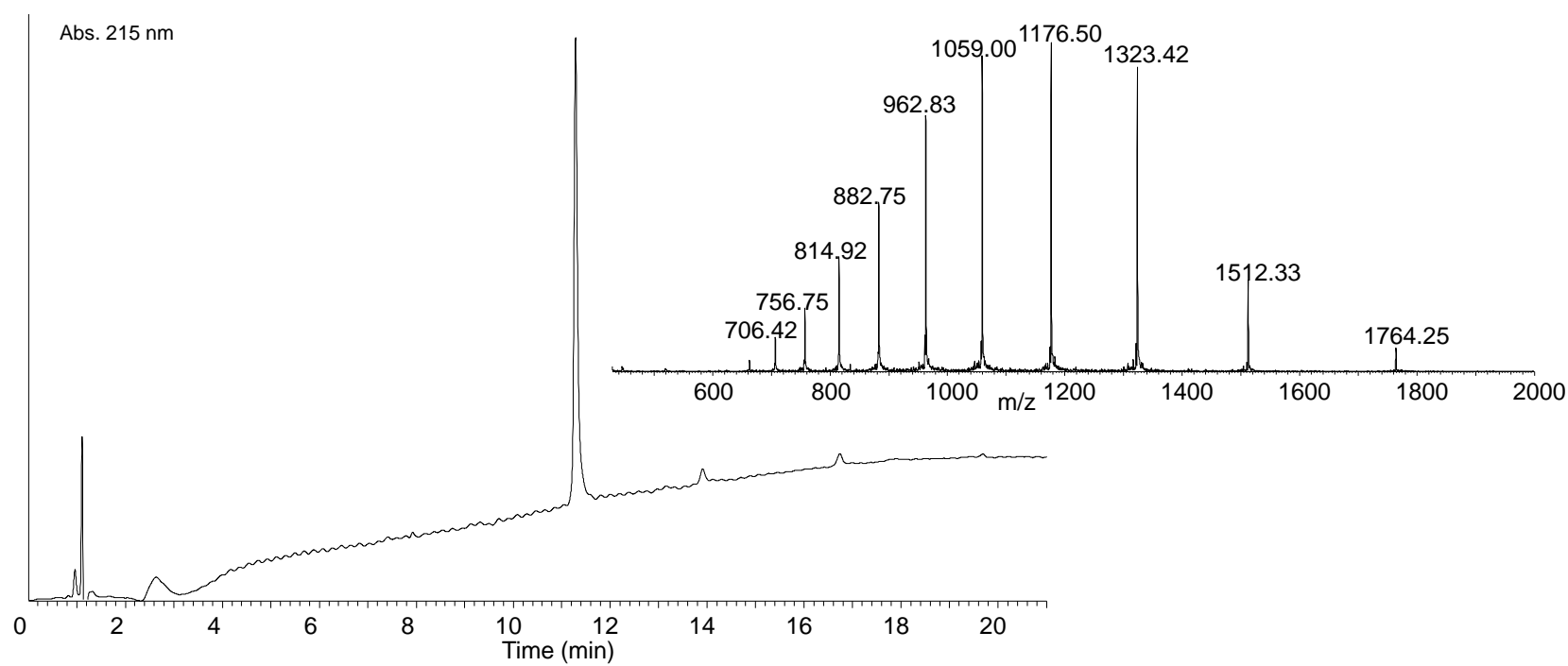

Figure S 4. Analysis of SUMO-2 Lys(Cys) 6a. UPLC-MS analysis ACQUITY UPLC peptide BEH C18 $300 \AA 1.7 \mu \mathrm{m}$ $2.1 \mathrm{~mm} \times 150 \mathrm{~mm}, 50{ }^{\circ} \mathrm{C}$. Flow $0.400 \mathrm{~mL} / \mathrm{min}$, eluent $A 0.1 \%$ trifluoroacetic acid in water, eluent $B 0.1 \%$ trifluoroacetic acid in $100 \%$ acetonitrile. Gradient from $0 \%$ eluent B to $70 \%$ eluent B in 20 min. HPLC trace (UV detection) and MS trace. Calculated for M (average mass) 10580.88, observed 10579.75 after deconvolution. 


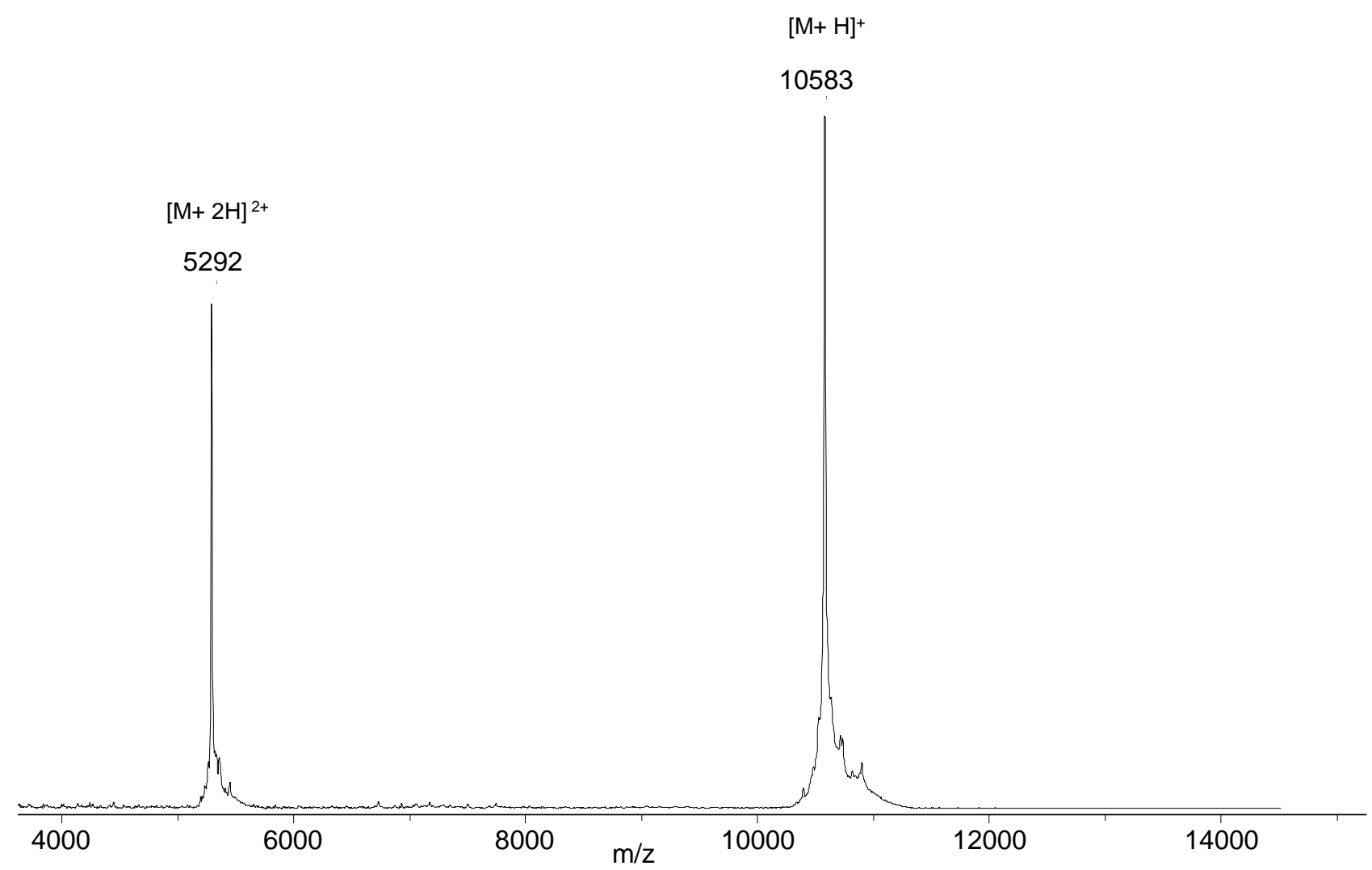

Figure $\mathbf{S} 5 \mathrm{MALDI}-\mathrm{TOF}$ analysis peptide $6 \mathrm{a}$. Matrix sinapinic acid, positive detection mode, linear mode $[\mathrm{M}+\mathrm{H}]^{+}$ calcd. (mean) 10582, found 10583.

2) One-pot synthesis and characterization of SUMO-3 Lys(Cys) 6b

Peptide $\mathbf{6 b}$ was prepared similarly using peptide $\mathbf{1 b}(2.57 \mathrm{mg}, 0.386 \mu \mathrm{mol})$ and peptide $4(2.27 \mathrm{mg}, 0.386$ $\mu \mathrm{mol})$.

The crude mixture was purified by semi-preparative HPLC using XBridge BEH300 C18 column (5 $\mu \mathrm{m}, 300 \AA$, $10 \times 250 \mathrm{~mm}$ ), eluent $A$ water containing $0.1 \%$ of TFA, eluent $\mathrm{B} \mathrm{CH}_{3} \mathrm{CN} /$ water : $4 / 1$ by vol containing $0.1 \%$ of TFA, gradient: $0-25 \%$ B in $5 \mathrm{~min}, 25-45 \%$ B in $50 \mathrm{~min}$, flow rate $6 \mathrm{~mL} / \mathrm{min}$, UV detection at $215 \mathrm{~nm}, 65^{\circ} \mathrm{C}$ to give $6 \mathbf{b}$ (1.65 mg, $64 \%$ overall isolated). 
Peptide 6b: SEEKPKEGVK(C)TENDHINLKVAGQDGSVVQFKIKRHTPLSKLMKAYCERQGLSMRQIRFR FDGQPINETDTPAQLEMEDEDTIDVFQQQTGG

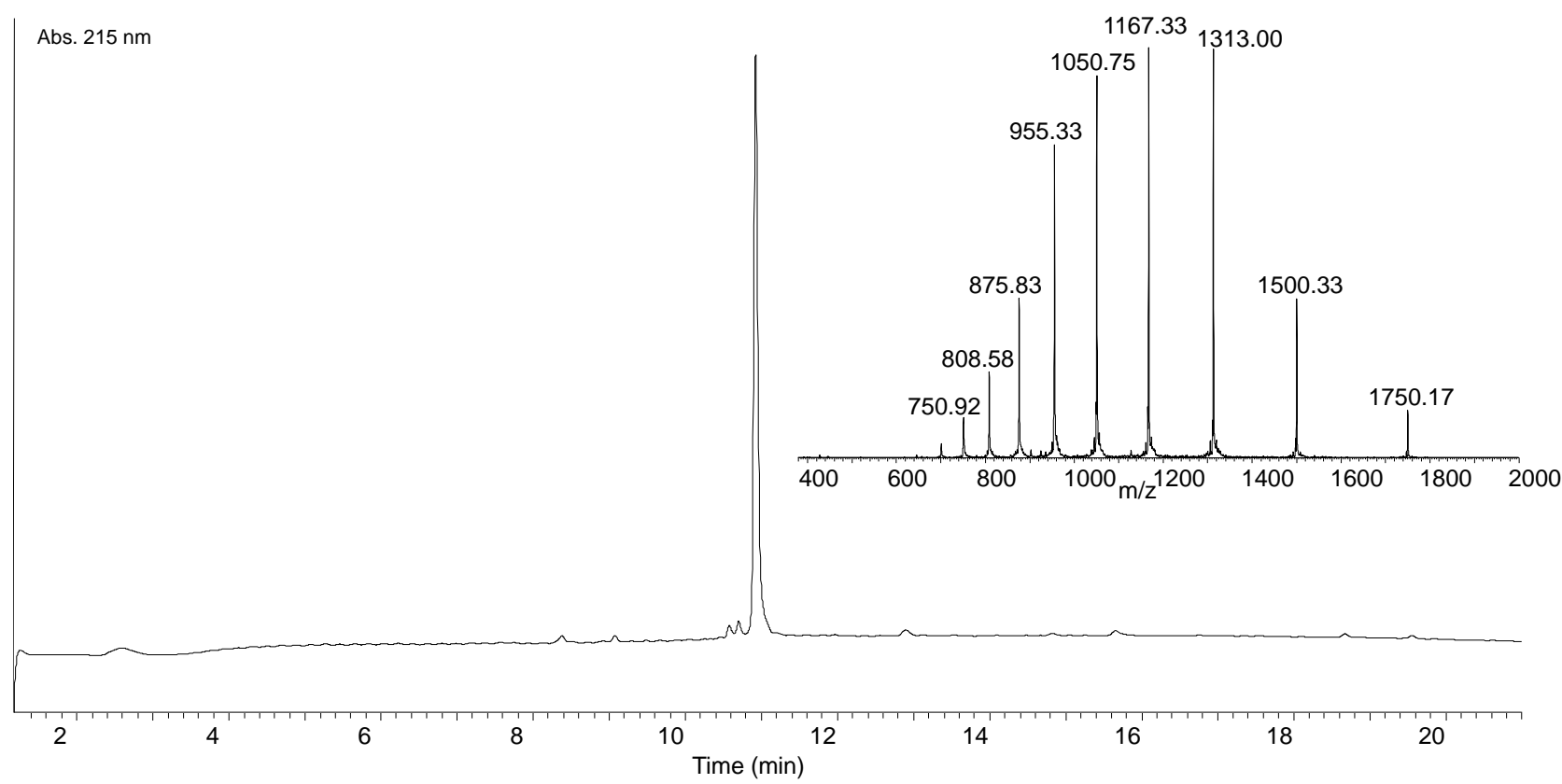

Figure S 6. Analysis of SUMO-3 Lys(Cys) 6b. UPLC-MS analysis ACQUITY UPLC peptide BEH C18 $300 \AA 1.7 \mu \mathrm{m}$ $2.1 \mathrm{~mm} \times 150 \mathrm{~mm}, 50{ }^{\circ} \mathrm{C}$. Flow $0.400 \mathrm{~mL} / \mathrm{min}$, eluent $A 0.1 \%$ trifluoroacetic acid in water, eluent $B 0.1 \%$ trifluoroacetic acid in 100\% acetonitrile. Gradient from 0\% eluent B to $70 \%$ eluent B in 20 min. HPLC trace (UV detection) and MS trace. Calculated for M (average mass) 10496.80, observed 10496.49 after deconvolution. 


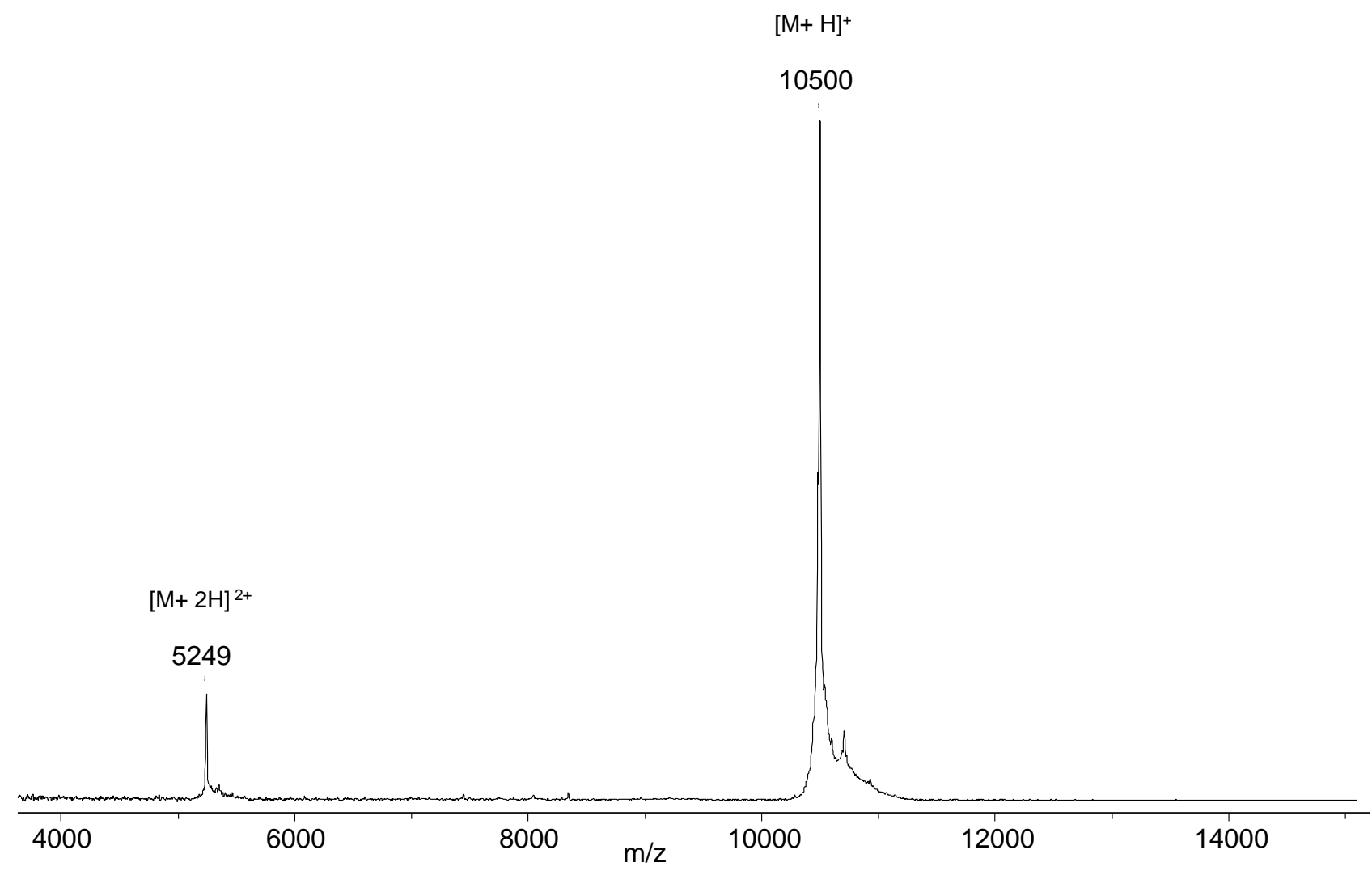

Figure $\mathbf{S} 7 \mathrm{MALDI}-\mathrm{TOF}$ analysis peptide $6 \mathrm{~b}$. Matrix sinapinic acid, positive detection mode, linear mode $[\mathrm{M}+\mathrm{H}]^{+}$ calcd. (mean) 10498, found 10500.

3) One-pot synthesis and characterization of SUMO-3 Lys(Cys) hydrazide 7

Peptide $\mathbf{7}$ was prepared similarly using peptide $\mathbf{1 b}(2.86 \mathrm{mg}, 0.429 \mu \mathrm{mol})$ and peptide $\mathbf{5}(2.53 \mathrm{mg}, 0.429$ $\mu \mathrm{mol})$.

The crude mixture was purified by semi-preparative HPLC using column XBridge BEH300 C18 (5 $\mu \mathrm{m}, 300 \AA$, $10 \times 250 \mathrm{~mm}$ ), eluent $A$ water containing $0.1 \%$ of TFA, eluent $B \mathrm{CH}_{3} \mathrm{CN} /$ water : $4 / 1$ by vol containing $0.1 \%$ of TFA, gradient: $0-25 \% \mathrm{~B}$ in $5 \mathrm{~min}, 25-45 \%$ B in $50 \mathrm{~min}$, flow rate $6 \mathrm{~mL} / \mathrm{min}$, UV detection at $215 \mathrm{~nm}, 65^{\circ} \mathrm{C}$ to give 7 ( $1.67 \mathrm{mg}, 58 \%$ overall isolated). 


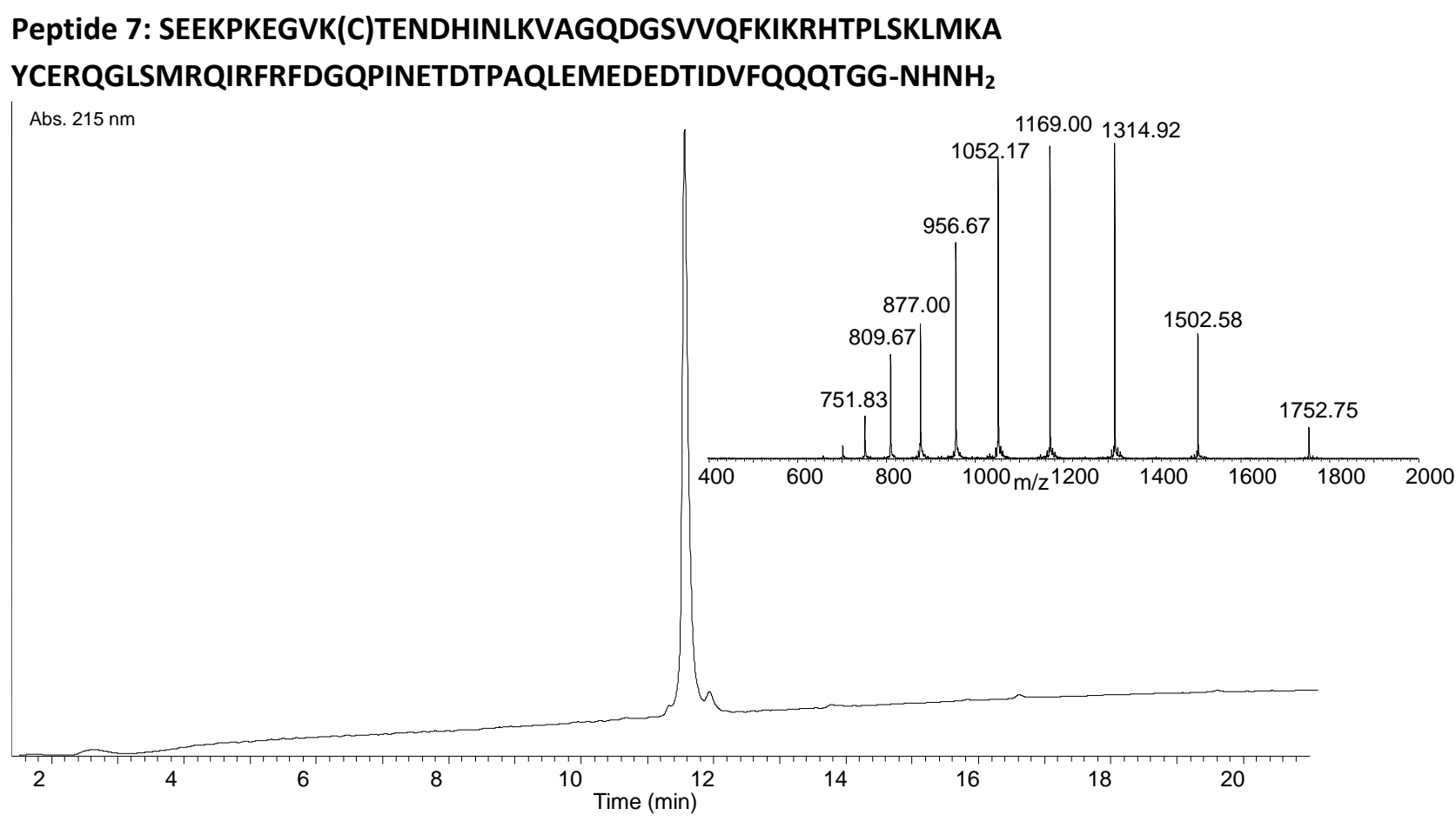

Figure S 8. Analysis of SUMO-3 Lys(Cys) hydrazide 7. UPLC-MS analysis ACQUITY UPLC peptide BEH C18 300 $\AA 1.7 \mu \mathrm{m} 2.1 \mathrm{~mm} \times 150 \mathrm{~mm}, 50^{\circ} \mathrm{C}$. Flow $0.400 \mathrm{~mL} / \mathrm{min}$, eluent $A 0.1 \%$ trifluoroacetic acid in water, eluent $B$ $0.1 \%$ trifluoroacetic acid in $100 \%$ acetonitrile. Gradient from $0 \%$ eluent B to $70 \%$ eluent B in 20 min. HPLC trace (UV detection) and MS trace. Calculated for M (average mass) 10510.83, observed 10511.85 after deconvolution. 


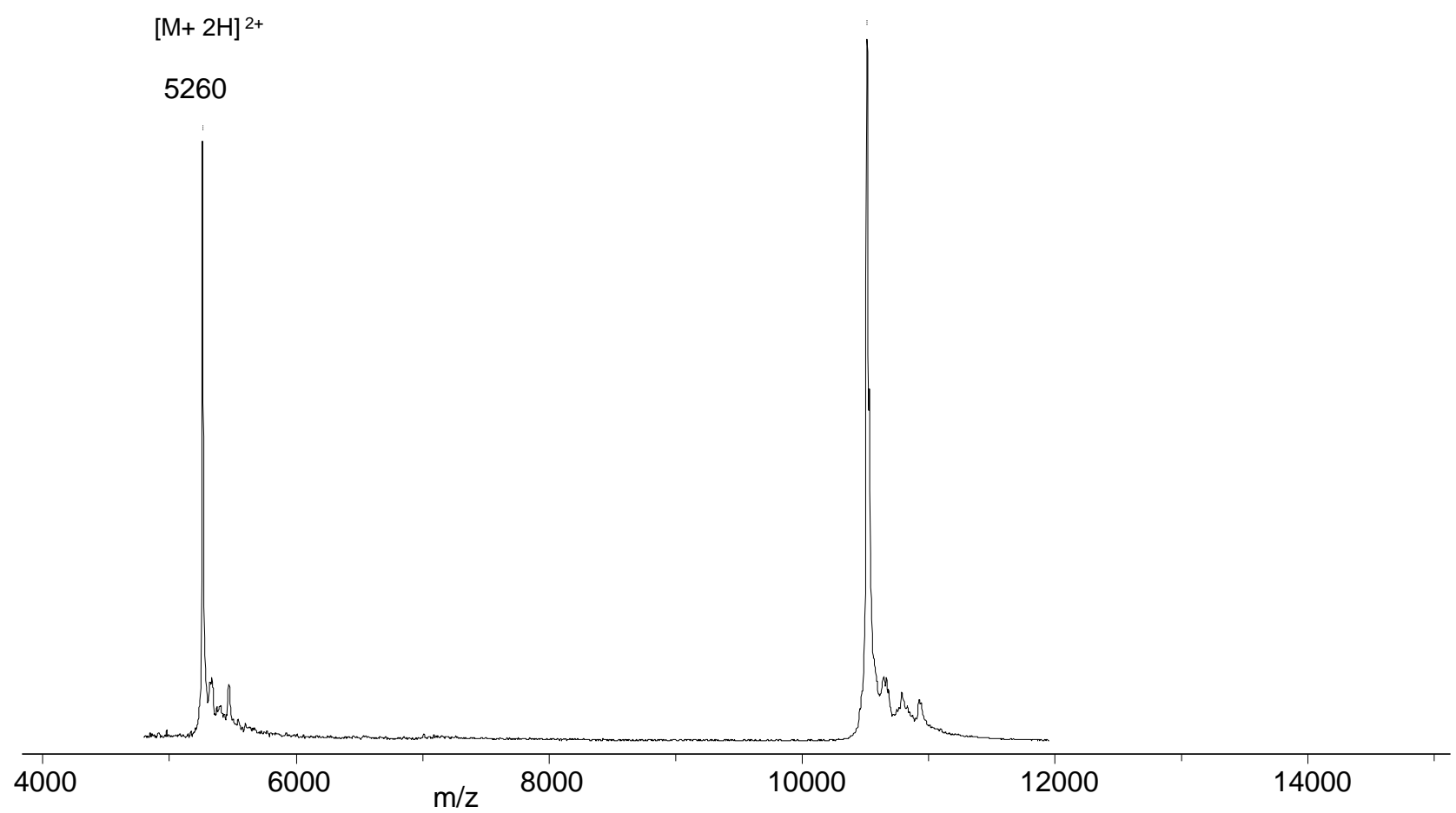

Figure $\mathbf{S} 9 \mathrm{MALDI}-\mathrm{TOF}$ analysis of peptide 7. Matrix sinapinic acid, positive detection mode, linear mode $[\mathrm{M}+\mathrm{H}]^{+}$calcd. (mean) 10512, found 10515.

\section{B. Chemical synthesis of SUMO-2/3 dimers}

A typical procedure is illustrated with the synthesis of SUMO-2/3 dimer 11.

\section{1) Synthesis of SUMO dimer 11}

\section{Step 1. Synthesis of SUMO-2 SEA ${ }^{\text {off }} \mathbf{1 0 a}$}

A solution of $\mathrm{N}$-octylglucoside $(6.90 \mathrm{mg}, 20 \mathrm{mM})$ in $6 \mathrm{M}$ guanidinium chloride/ $0.1 \mathrm{M} \mathrm{pH} 7.0$ sodium phosphate buffer $(1.180 \mathrm{~mL}$ ) was prepared (solution A). Solution A $(501 \mu \mathrm{L})$ was used to dissolve 4-mercaptophenylacetic acid (MPAA, $16.85 \mathrm{mg}, 200 \mathrm{mM}$ ) and the $\mathrm{pH}$ of the mixture was then adjusted to 7.2 with $6 \mathrm{~N} \mathrm{NaOH}$ to give solution $B$.

Thioester peptide $8 \mathrm{a}(2.04 \mathrm{mg}, 0.308 \mu \mathrm{mol}, 5 \mathrm{mM})$ and peptide $9(1.85 \mathrm{mg}, 0.308 \mu \mathrm{mol}, 5 \mathrm{mM}, 1$ equiv) were dissolved in solution $\mathrm{B}(62 \mu \mathrm{L})$ and the reaction mixture was stirred at $25{ }^{\circ} \mathrm{C}$ for $25 \mathrm{~h}$ under nitrogen atmosphere to give the solution $C$.

The progress of the reaction was monitored by HPLC. For each analysis, a $1.5 \mu \mathrm{L}$ aliquot was taken from the reaction mixture and quenched by adding $100 \mu \mathrm{L}$ of $10 \%$ acetic acid. The sample was then extracted with $\mathrm{Et}_{2} \mathrm{O}$ to remove MPAA prior to HPLC analysis.

Step 2. Assembly of the dimer 
A fresh solution of $N$-octylglucoside $(6.90 \mathrm{mg}, 20 \mathrm{mM})$ in $6 \mathrm{M}$ guanidinium chloride/0.1 M pH 7.0 sodium phosphate buffer $(1.180 \mathrm{~mL}$ ) was prepared again (solution D). Solution $\mathrm{D}(421 \mu \mathrm{L})$ was used to dissolve TCEP (24.14 mg, $84.20 \mu \mathrm{mol}, 200 \mathrm{mM})$ to give the solution E. Then MPAA (14.16 mg, $84.20 \mu \mathrm{mol}, 200 \mathrm{mM})$ was dissolved in solution $\mathrm{E}(421 \mu \mathrm{L})$ and the $\mathrm{pH}$ of the solution was adjusted to 5.5 with $6 \mathrm{~N} \mathrm{NaOH}$ to give solution F. Peptide $6 a(3.8 \mathrm{mg}, 0.307 \mu \mathrm{mol}, 5 \mathrm{mM})$ was dissolved in solution $\mathrm{F}(60 \mu \mathrm{L})$ to give solution $\mathrm{G}$.

Solutions $\mathrm{C}$ and $\mathrm{G}$ were mixed and the $\mathrm{pH}$ was adjusted to 5.5 by addition of $6 \mathrm{~N} \mathrm{NaOH}$. The final peptide concentration was $2.5 \mathrm{mM}$. The reaction was agitated for $96 \mathrm{~h}$ and then acidified with glacial acetic acid (10 $\mu \mathrm{L})$ to quench the reaction. The solution was extracted with diethyl ether $(3 \times 2 \mathrm{~mL})$ to remove the excess of MPAA. The mixture was immediately purified by HPLC to yield $1.85 \mathrm{mg}$ ( $36 \%$ overall isolated) of SUMO dimer 11.

\section{2) Synthesis of SUMO dimer 12}

SUMO-3 SEA ${ }^{\text {off }} \mathbf{1 0 b}$ was prepared using the thioester peptide $\mathbf{8 b}(2.36 \mathrm{mg}, 0.362 \mu \mathrm{mol}, 5 \mathrm{mM})$ and peptide $\mathbf{9}$ (2.17 mg, $0.362 \mu \mathrm{mol})$ and ligated with SUMO-3 Lys(Cys) $6 \mathbf{b}(4.50 \mathrm{mg}, 0.360 \mu \mathrm{mol})$ as described for dimer 11.

The reaction was acidified with glacial acetic acid $(10 \mu \mathrm{L})$ to quench the reaction. The solution was extracted with diethyl ether $(3 \times 2 \mathrm{~mL})$ to remove the excess of MPAA. The mixture was immediately purified by HPLC to yield $0.836 \mathrm{mg}$ ( $22 \%$ overall isolated) of SUMO dimer 12 .

\section{3) Synthesis of SUMO dimer 13}

SUMO-2 SEA ${ }^{\text {off }} 10$ a was prepared using thioester peptide 8 a $(2.04 \mathrm{mg}, 0.308 \mu \mathrm{mol}, 5 \mathrm{mM})$ and peptide 9 (1.85 $\mathrm{mg}, 0.308 \mu \mathrm{mol}, 5 \mathrm{mM}, 1$ equiv) and ligated with SUMO-3 Lys(Cys) $6 \mathbf{b}(3.80 \mathrm{mg}, 0.303 \mu \mathrm{mol})$ as described for dimer 11.

The reaction was acidified with glacial acetic acid $(10 \mu \mathrm{L})$ to quench the reaction. The solution was extracted with diethyl ether $(3 \times 2 \mathrm{~mL})$ to remove the excess of MPAA. The mixture was immediately purified by HPLC to yield $1.102 \mathrm{mg}$ ( $29 \%$ overall isolated) of SUMO dimer 13.

\section{4) Synthesis of SUMO dimer 14}

SUMO-3 SEA ${ }^{\text {off }} 10 \mathrm{~b}$ was prepared using thioester peptide $8 \mathbf{b}$ ( $2.36 \mathrm{mg}, 0.362 \mu \mathrm{mol}, 5 \mathrm{mM}$ ) and peptide $\mathbf{9}$ ( 2.17 $\mathrm{mg}, 0.362 \mu \mathrm{mol}, 5 \mathrm{mM}, 1.0$ equiv) and ligated with SUMO-2 Lys(Cys) $6 a(4.40 \mathrm{mg}, 0.363 \mu \mathrm{mol})$ as described for dimer 11.

The reaction was acidified with glacial acetic acid $(10 \mu \mathrm{L})$ to quench the reaction. The solution was extracted with diethyl ether $(3 \times 2 \mathrm{~mL})$ to remove the excess of MPAA. The mixture was immediately purified by HPLC to yield $0.874 \mathrm{mg}$ ( $23 \%$ overall isolated) of SUMO dimer 14.

\section{5) Synthesis and characterization of SUMO dimer 15}

SUMO-2 SEA ${ }^{\text {off }} 10$ a was prepared using thioester peptide $8 \mathrm{a}(2.04 \mathrm{mg}, 0.308 \mu \mathrm{mol}, 5 \mathrm{mM})$ and peptide 9 (1.85 $\mathrm{mg}, 0.308 \mu \mathrm{mol}, 5 \mathrm{mM}, 1$ equiv) and ligated with SUMO-3 Lys(Cys) $(4.50 \mathrm{mg}, 0.360 \mu \mathrm{mol})$ as described for dimer 11. 
The reaction was acidified with glacial acetic acid $(10 \mu \mathrm{L})$ to quench the reaction. The solution was extracted with diethyl ether $(3 \times 2 \mathrm{~mL})$ to remove the excess of MPAA. The mixture was immediately purified by HPLC to yield $0.555 \mathrm{mg}$ ( $13 \%$ overall isolated) of SUMO dimer 15 .

\section{Desulfurization of SUMO-2/3 dimers}

The desulfurization protocols in native or denaturing conditions were optimized and validated using SUMO2/3 dimer 13.

- Desulfurization of SUMO-2/3 dimer 13 in denaturing conditions

SUMO-2/3 dimer 13 ( $0.130 \mathrm{mg}, 6.20 \mu \mathrm{mol}, 0.048 \mathrm{mM}$ final concentration) was dissolved in a solution of TCEP (57.3 mg/mL, $200 \mathrm{mM}$ final concentration), 2,2'-azobis[2-(2-imidazolin-2-yl)propane]dihydrochloride (VA$044,6.50 \mathrm{mg} / \mathrm{mL}, 20 \mathrm{mM}$ final concentration), methionine (Met, $2.98 \mathrm{mg} / \mathrm{mL}, 20 \mathrm{mM}$ final concentration) and reduced glutathione (GSH, $15.40 \mathrm{mg} / \mathrm{mL}, 50 \mathrm{mM}$ final concentration) in $6 \mathrm{M}$ guanidinium chloride/ 0.1 $\mathrm{M} \mathrm{pH} 7.2$ ammonium phosphate buffer $(3492 \mu \mathrm{L})$. The desulfurization was carried out at $25^{\circ} \mathrm{C}$ and monitored by UPLC-MS. The reaction product was SUMO-2/3 dimer 20. 


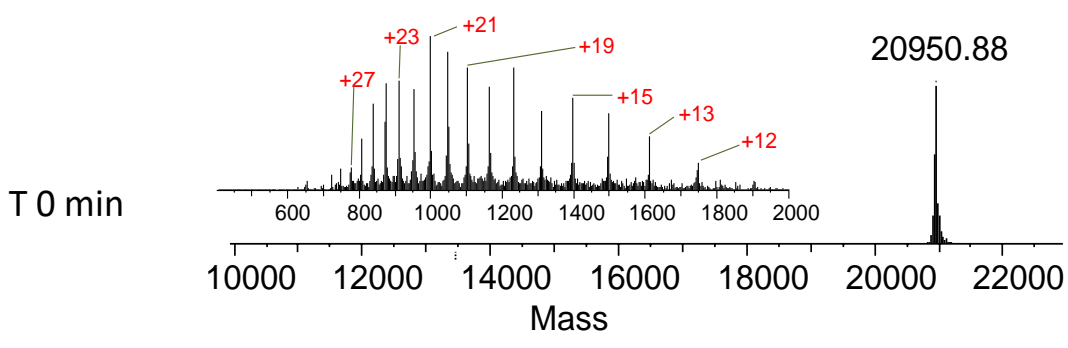

T $67 \mathrm{~min}$

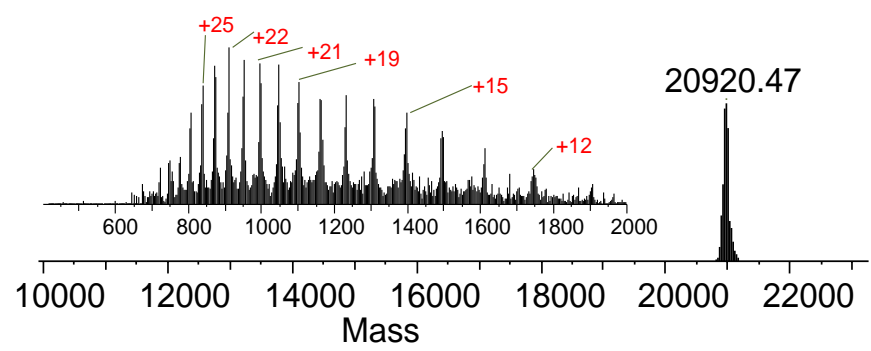

T $234 \min$

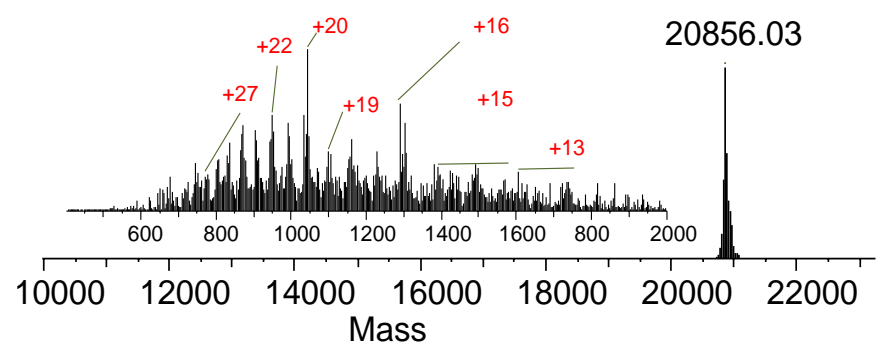

Figure $\mathbf{S}$ 10. Analysis of the desulfurization reaction in denaturing condition and leading to the production of SUMO-2/3 dimer 20. UPLC-MS analysis using ATLANTIS waters T3column $(3 \mu \mathrm{m} 2.1 \mathrm{~mm} \times 50 \mathrm{~mm}) .50^{\circ} \mathrm{C}$, flow $0.400 \mathrm{~mL} / \mathrm{min}$, eluent $\mathrm{A} 0.1 \%$ trifluoroacetic acid in water, eluent B $0.1 \%$ trifluoroacetic acid in $100 \%$ aqueous acetonitrile. Gradient from $0 \%$ eluent B to $70 \%$ eluent B in 4 min. MS trace.

\section{- Desulfurization of SUMO-2/3 dimer 13 in native conditions}

SUMO-2/3 dimer $13(0.136 \mathrm{mg}, 6.49 \mu \mathrm{mol}, 0.048 \mathrm{mM}$ final concentration) was dissolved in a solution of TCEP (57.3 mg/mL, $200 \mathrm{mM}$ final concentration), 2,2'-azobis[2-(2-imidazolin-2-yl)propane]dihydrochloride (VA$044,6.50 \mathrm{mg} / \mathrm{mL}, 20 \mathrm{mM}$ final concentration), methionine (Met, $2.98 \mathrm{mg} / \mathrm{mL}, 20 \mathrm{mM}$ final concentration) and reduced glutathione (GSH, $15.40 \mathrm{mg} / \mathrm{mL}, 50 \mathrm{mM}$ final concentration) in $0.1 \mathrm{M} \mathrm{pH} 7.2$ ammonium phosphate buffer $(3492 \mu \mathrm{L})$. The desulfurization was carried out at $25{ }^{\circ} \mathrm{C}$ and monitored by UPLC-MS. The reaction yielded selectively SUMO-2/3 dimer 18. 
To min

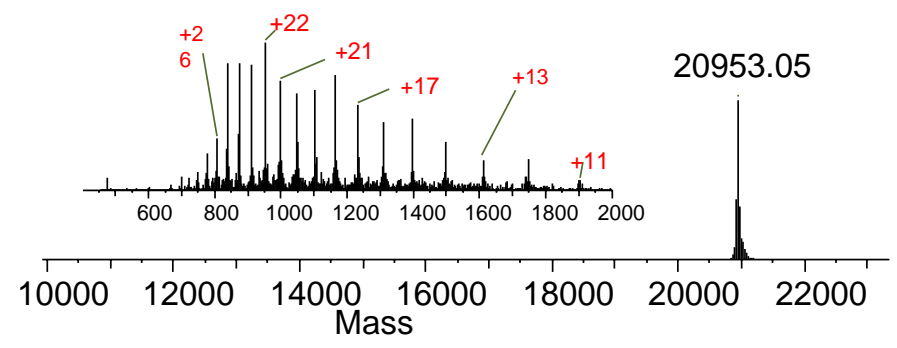

T $140 \mathrm{~min}$

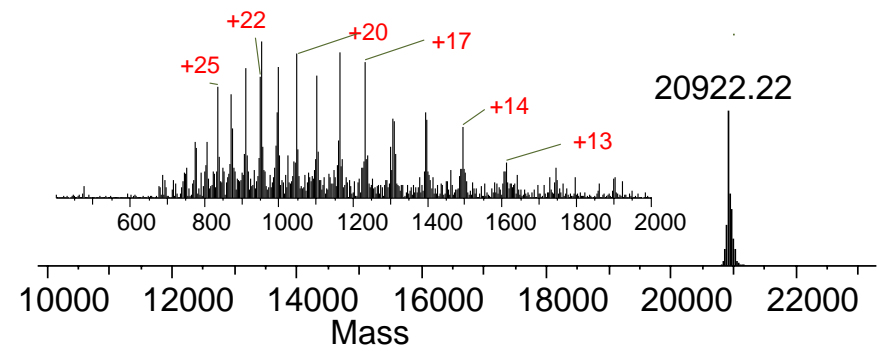

T $240 \mathrm{~min}$

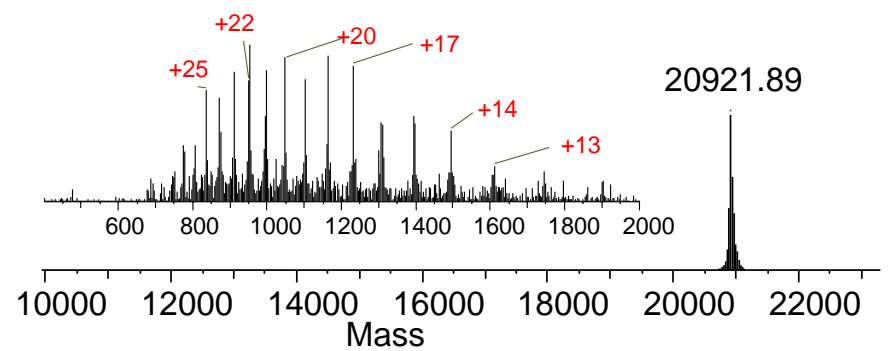

Figure $\mathbf{S}$ 11. Analysis of the desulfurization reaction in native conditions. UPLC-MS analysis using ATLANTIS waters T3column $(3 \mu \mathrm{m}, 2.1 \mathrm{~mm} \times 50 \mathrm{~mm}), 50{ }^{\circ} \mathrm{C}$. Flow $0.400 \mathrm{~mL} / \mathrm{min}$, eluent $\mathrm{A} 0.1 \%$ trifluoroacetic acid in water, eluent B $0.1 \%$ trifluoroacetic acid in $100 \%$ aqueous acetonitrile. Gradient from $0 \%$ eluent B to $70 \%$ eluent $B$ in 4 min. MS trace.

This protocol was applied to the selective desulfurization of SUMO-2/3 dimers 11-14.

SUMO-2/3 dimer 16 was prepared by desulfurization of SUMO-2/3 dimer $11(0.050 \mathrm{mg}, 2.37 \mu \mathrm{mol}, 0.048$ $\mathrm{mM}$ final concentration).

SUMO-2/3 dimer 17 was prepared by desulfurization of SUMO-2/3 dimer $12(0.050 \mathrm{mg}, 2.39 \mu \mathrm{mol}, 0.048$ $\mathrm{mM}$ final concentration).

SUMO-2/3 dimer 18 was prepared by desulfurization of SUMO-2/3 dimer 13 (0.61 mg, $0.46 \mu \mathrm{mol}, 0.10 \mathrm{mM}$ final concentration). The desulfurization was carried out at $25{ }^{\circ} \mathrm{C}$ and monitored by UPLC-MS. The mixture was purified by HPLC to yield $0.372 \mathrm{mg}$ (61\% isolated) of SUMO-2/3 dimer 18 .

SUMO-2/3 dimer 19 was prepared by desulfurization of SUMO-2/3 dimer $14(0.050 \mathrm{mg}, 2.38 \mu \mathrm{mol}, 0.048$ $\mathrm{mM}$ final concentration).

- UPLC-MS analysis 
A)

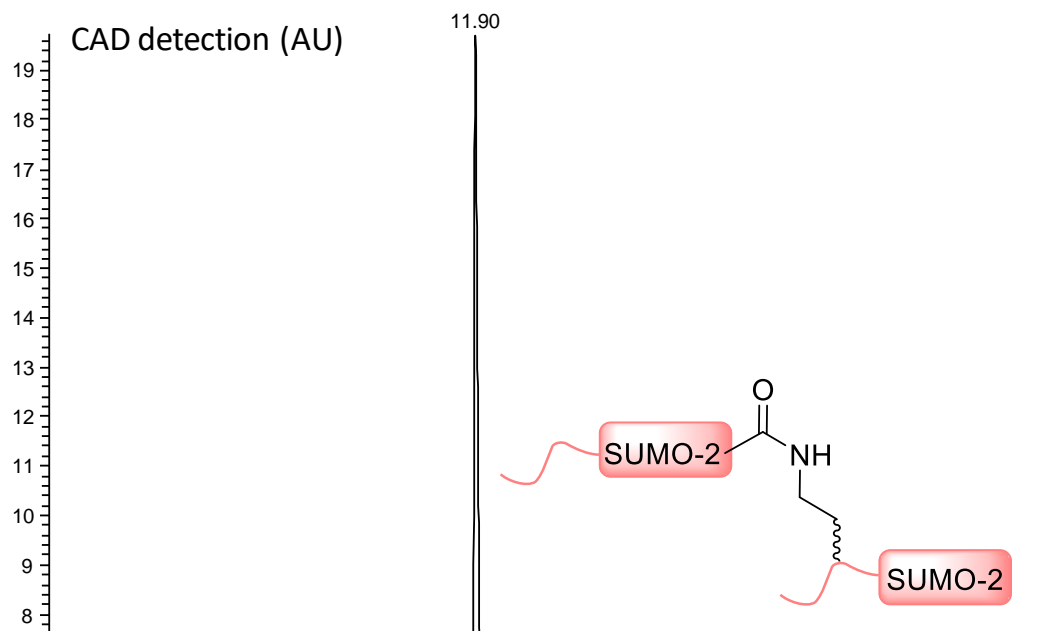

SUMO-2-SUMO-2 dimer 16

B)

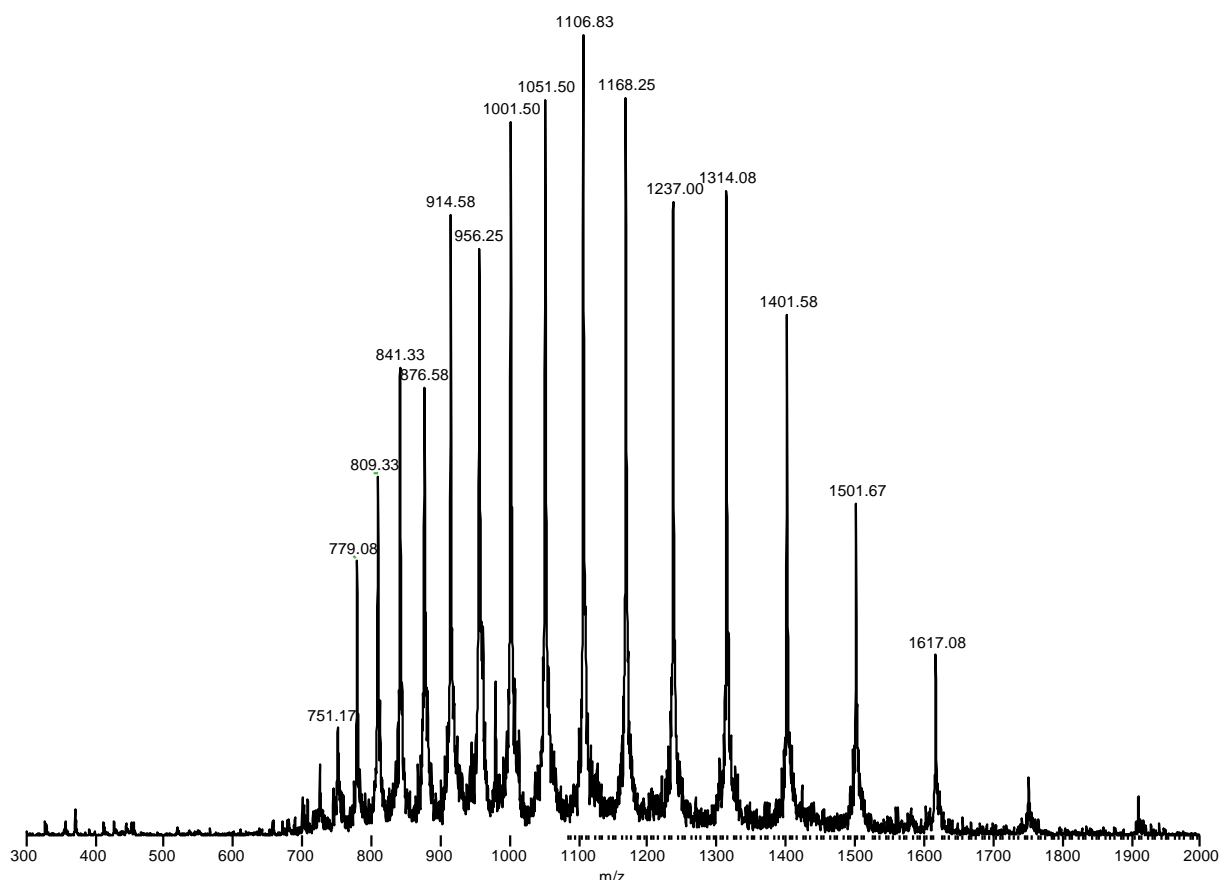

C) 


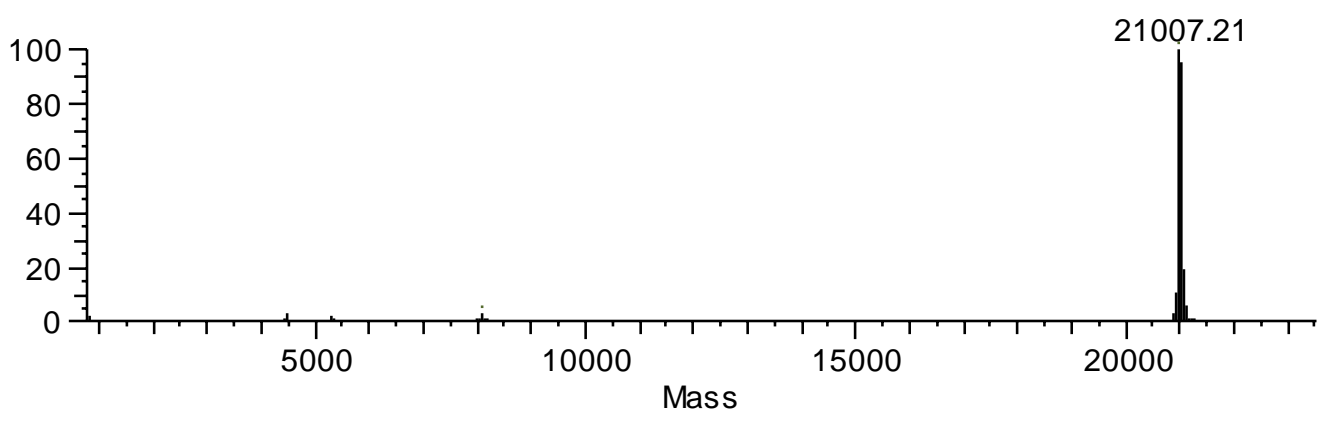

Figure S 12. LC-MS analysis of the desulfurized SUMO-2/3 dimers in native conditions. Formation of SUMO2-SUMO-2 dimer 16. A) LC-trace using charged aerosol detection (CAD, Dionex Corona Veo). B) MS trace. C) MS trace after deconvolution. UPLC-MS analysis ACQUITY UPLC peptide BEH C18 $300 \AA 1.7 \mu \mathrm{m}(2.1 \mathrm{~mm} \times$ $150 \mathrm{~mm}$ ), $50^{\circ} \mathrm{C}$. Flow $0.400 \mathrm{~mL} / \mathrm{min}$, eluent $A 0.1 \%$ trifluoroacetic acid in water, eluent $B 0.1 \%$ trifluoroacetic acid in $100 \%$ acetonitrile. Gradient from $0 \%$ eluent B to $70 \%$ eluent B in $20 \mathrm{~min}$.

A)

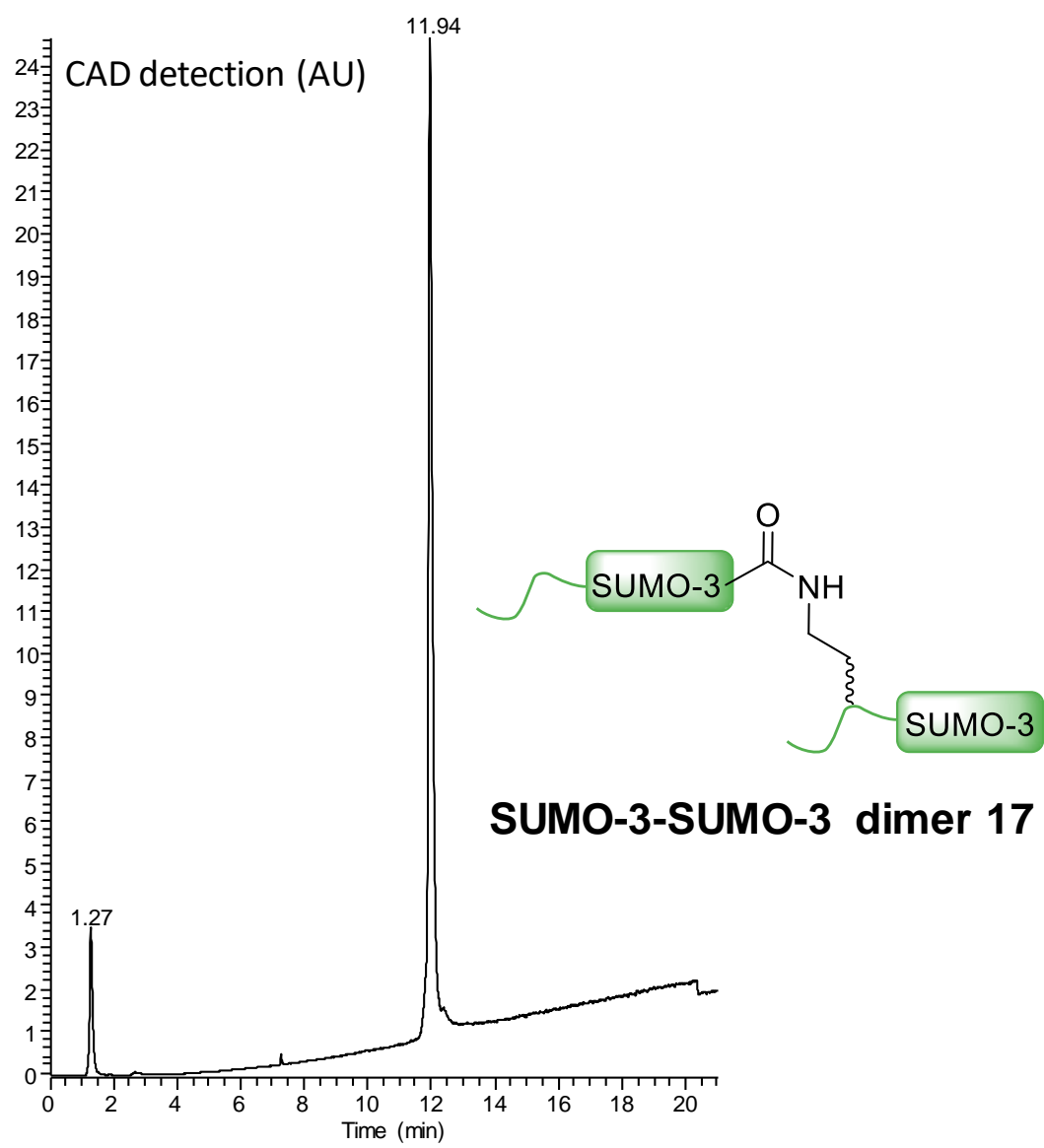

B) 


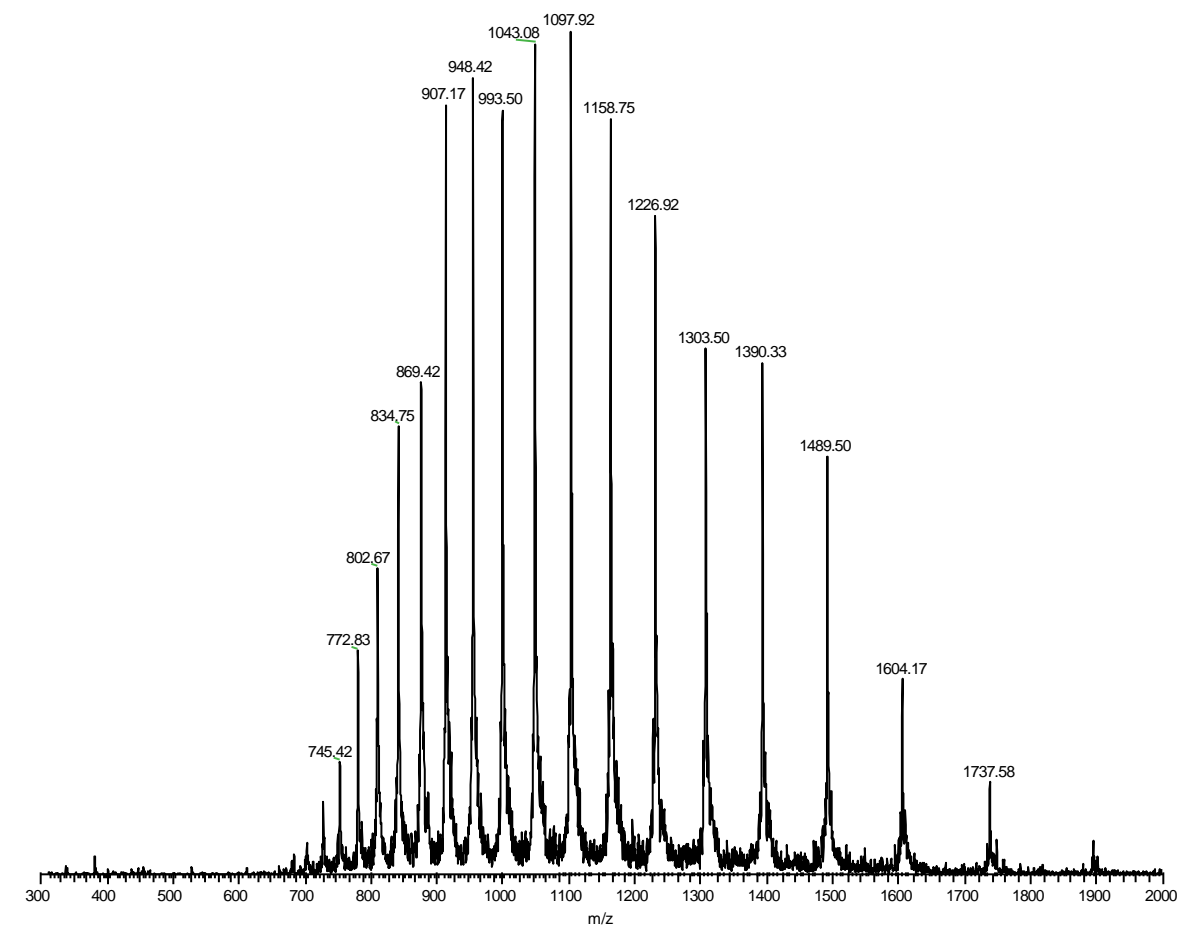

C)

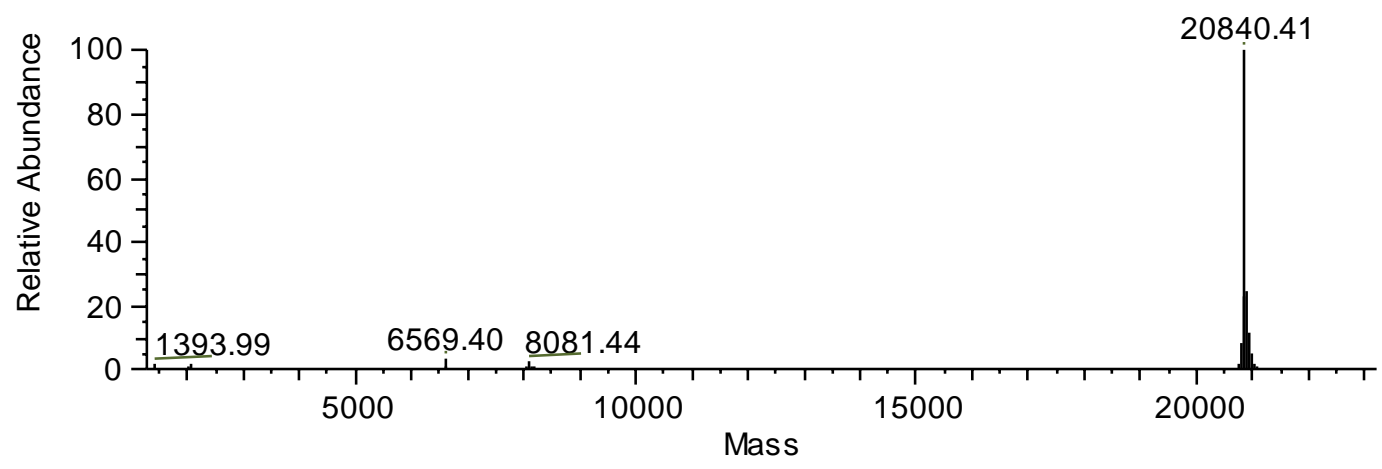

Figure S 13. LC-MS analysis of the desulfurized SUMO-2/3 dimers in native conditions. Formation of SUMO3-SUMO-3 dimer 17. A) LC-trace using charged aerosol detection (CAD, Dionex Corona Veo). B) MS trace. C) MS trace after deconvolution. UPLC-MS analysis ACQUITY UPLC peptide BEH C18 $300 \AA 1.7 \mu \mathrm{m}(2.1 \mathrm{~mm} \times$ $150 \mathrm{~mm}$ ), $50^{\circ} \mathrm{C}$. Flow $0.400 \mathrm{~mL} / \mathrm{min}$, eluent $A 0.1 \%$ trifluoroacetic acid in water, eluent $B 0.1 \%$ trifluoroacetic acid in 100\% acetonitrile. Gradient from 0\% eluent B to $70 \%$ eluent B in 20 min.

A) 


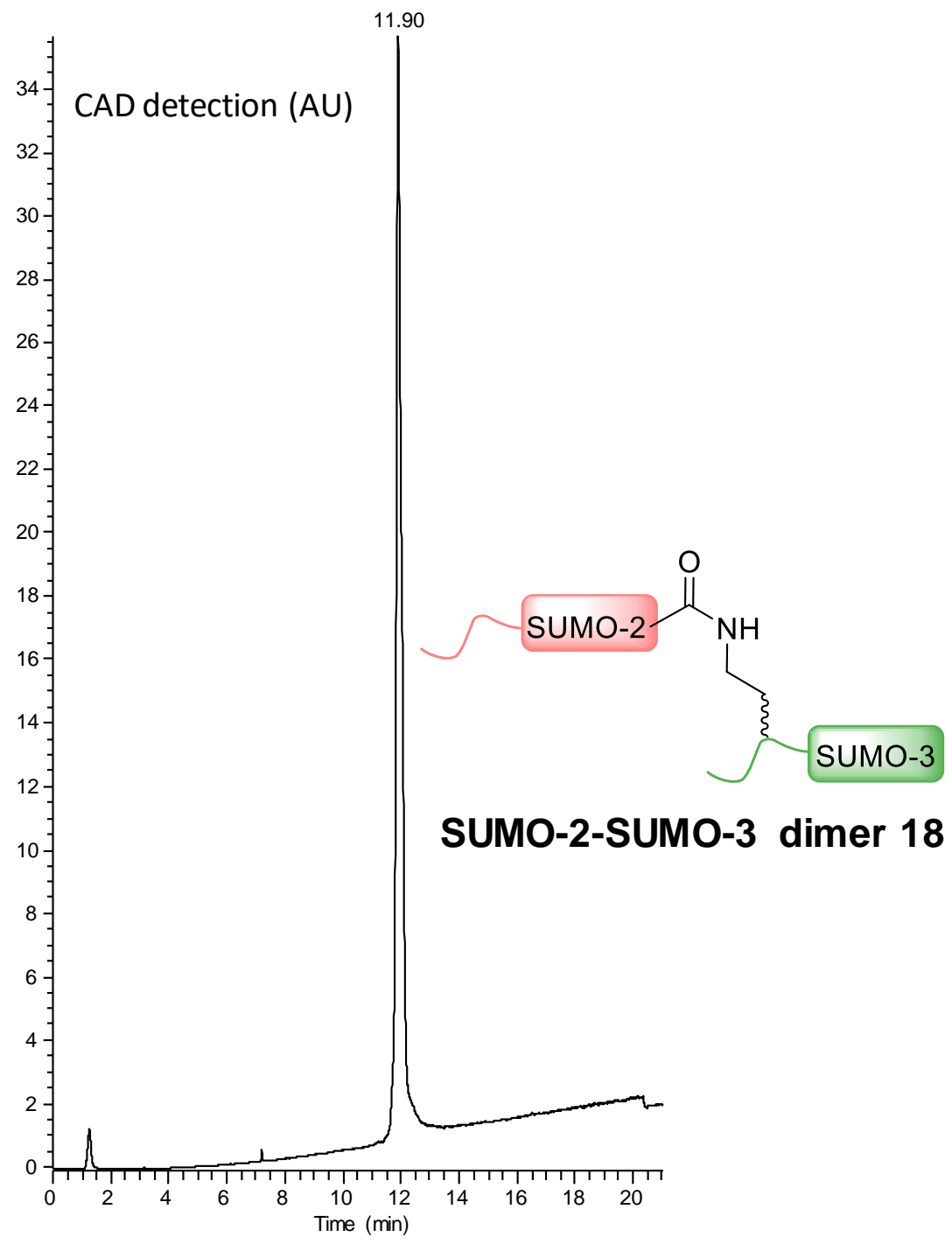

B) 


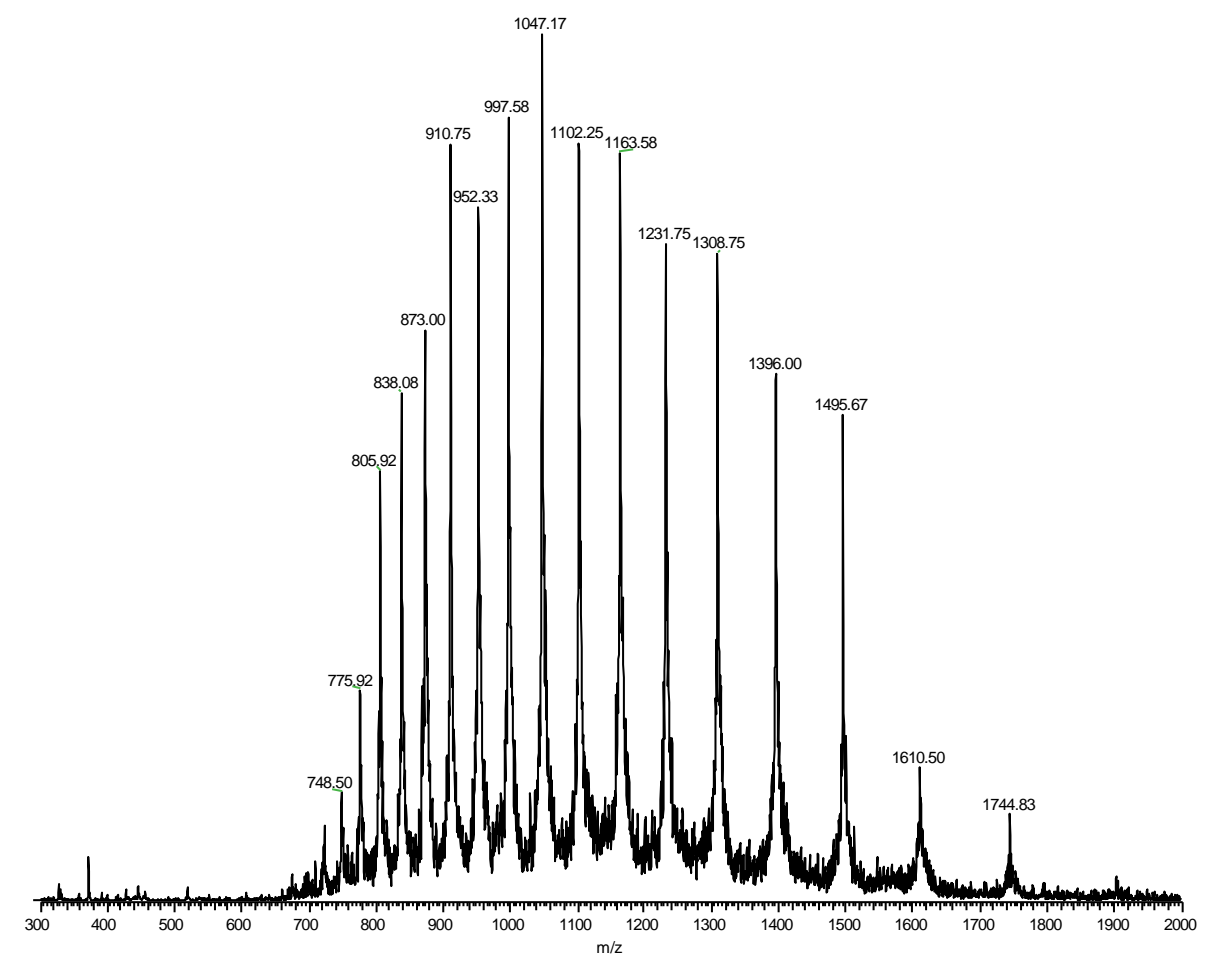

C)

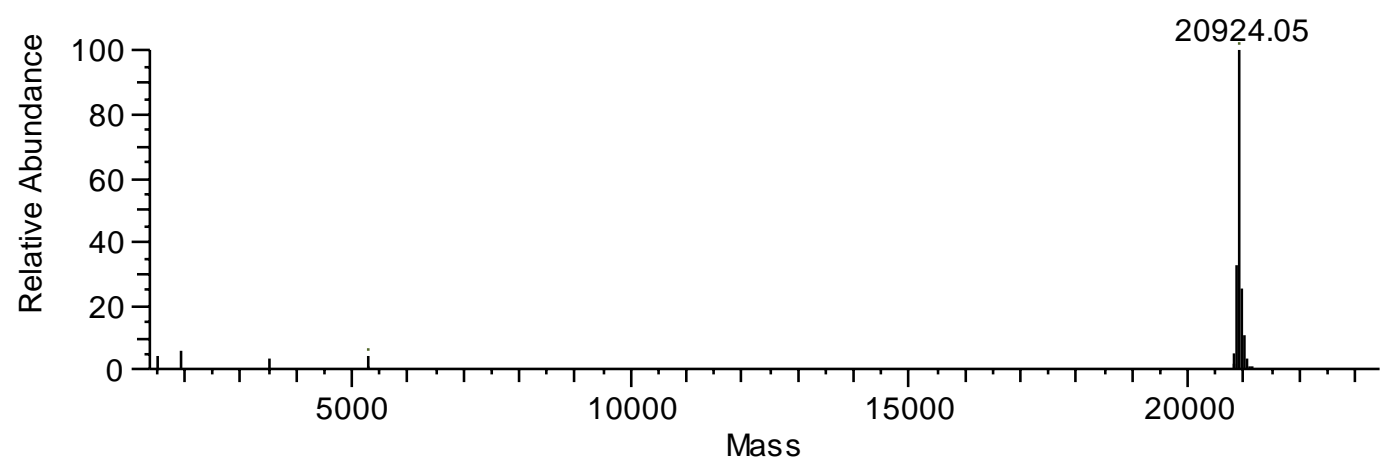

Figure S 14. LC-MS analysis of the desulfurized SUMO-2/3 dimers in native conditions. Formation of SUMO2-SUMO-3 dimer 18. A) LC-trace using charged aerosol detection (CAD, Dionex Corona Veo). B) MS trace. C) MS trace after deconvolution. UPLC-MS analysis ACQUITY UPLC peptide BEH C18 $300 \AA 1.7 \mu \mathrm{m}(2.1 \mathrm{~mm} \times$ $150 \mathrm{~mm}$ ), $50{ }^{\circ} \mathrm{C}$. Flow $0.400 \mathrm{~mL} / \mathrm{min}$, eluent $A 0.1 \%$ trifluoroacetic acid in water, eluent $B 0.1 \%$ trifluoroacetic acid in $100 \%$ acetonitrile. Gradient from $0 \%$ eluent B to $70 \%$ eluent B in $20 \mathrm{~min}$.

A) 


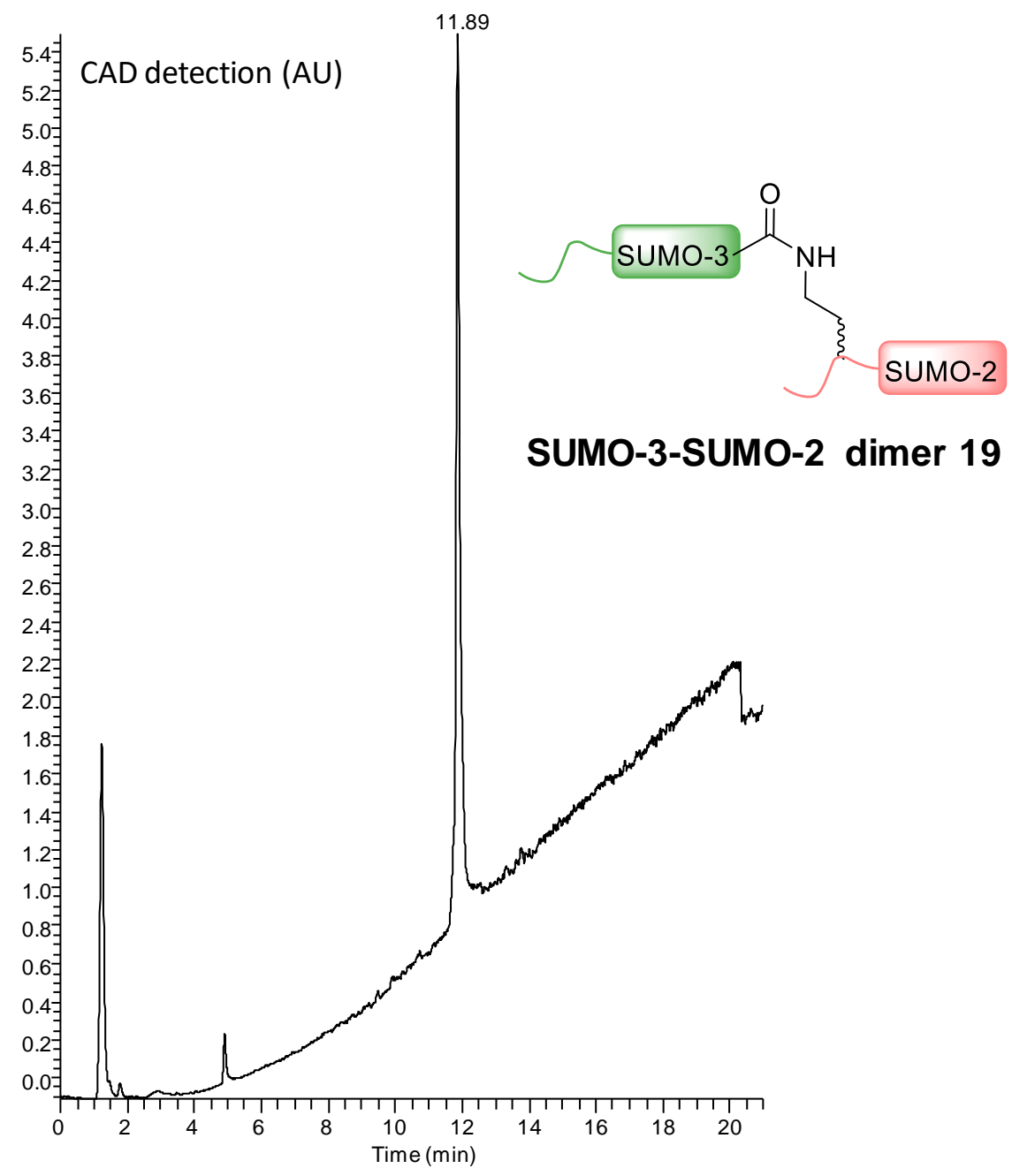

B) 


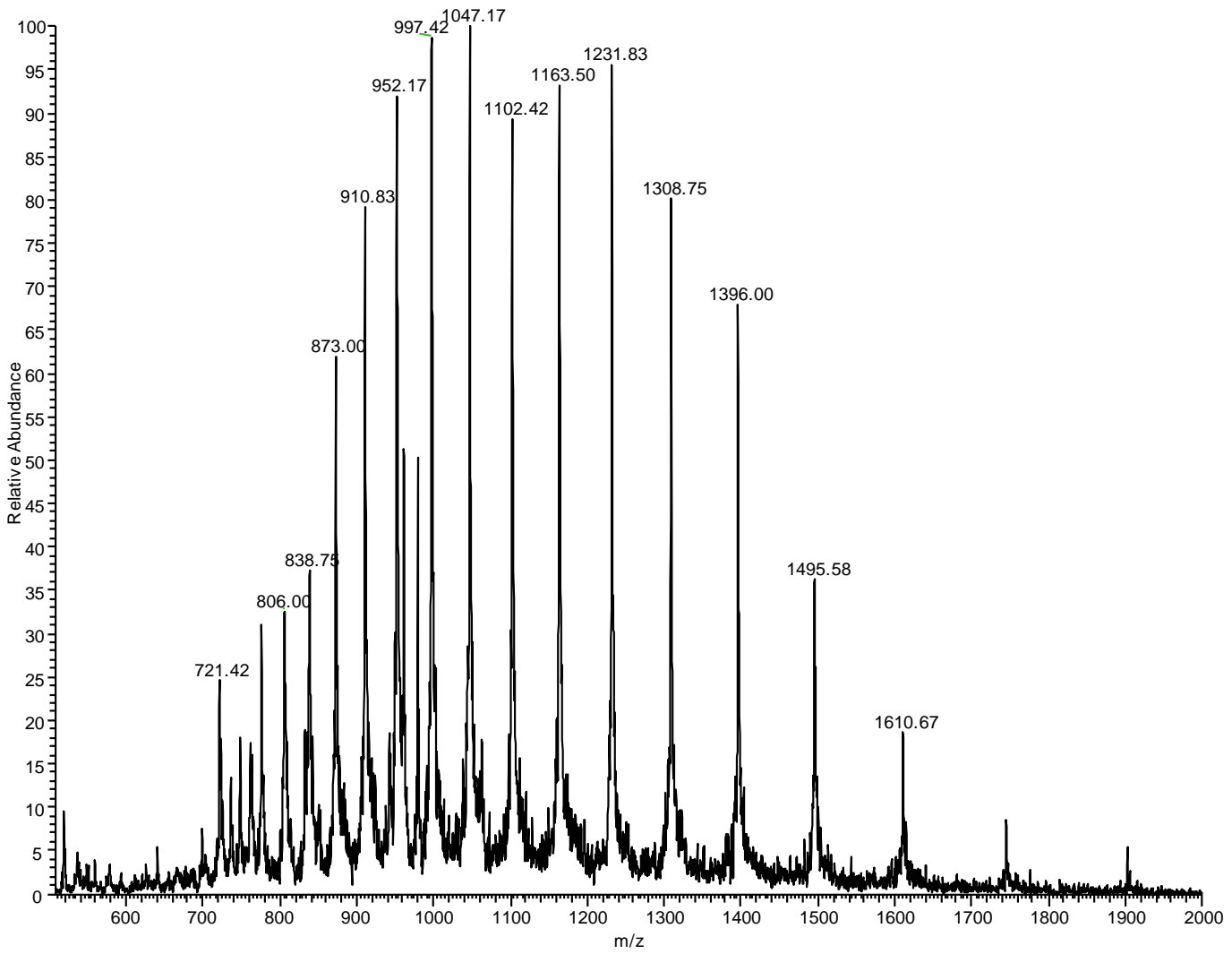

C)

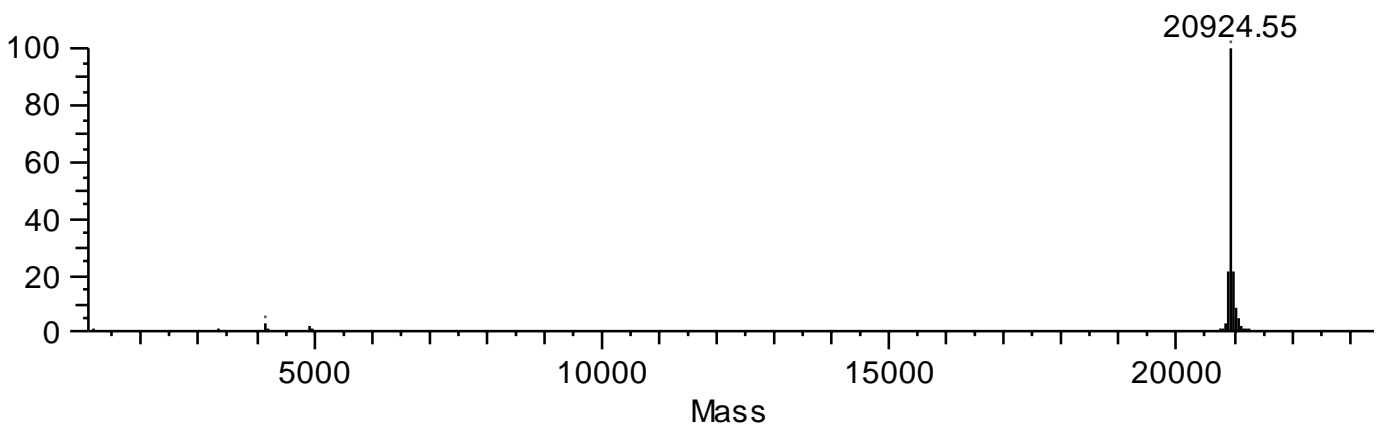

Figure S 15. LC-MS analysis of the desulfurized SUMO-2/3 dimers in native conditions. Formation of SUMO3-SUMO-2 dimer 19. A) LC-trace using charged aerosol detection (CAD, Dionex Corona Veo). B) MS trace. C) MS trace after deconvolution. UPLC-MS analysis ACQUITY UPLC peptide BEH C18 $300 \AA 1.7 \mu \mathrm{m}(2.1 \mathrm{~mm} \times$ $150 \mathrm{~mm}$ ), $50^{\circ} \mathrm{C}$. Flow $0.400 \mathrm{~mL} / \mathrm{min}$, eluent $A 0.1 \%$ trifluoroacetic acid in water, eluent $B 0.1 \%$ trifluoroacetic acid in $100 \%$ acetonitrile. Gradient from $0 \%$ eluent B to $70 \%$ eluent B in $20 \mathrm{~min}$. 


\section{Characterization of SUMO-2/3 dimers by proteomics analysis \\ Tryptic digestion}

The proteins were dissolved in $25 \mathrm{mM}$ ammonium bicarbonate $\mathrm{pH} 7.8(1 \mathrm{mg} / \mathrm{mL})$. The protein solution $(5 \mu \mathrm{L}$, $5 \mu \mathrm{g}$ ) was mixed with DTT ( $5 \mathrm{mg} / \mathrm{mL}, 1 \mu \mathrm{L}, 5 \mu \mathrm{g})$ and iodoacetamide $(10 \mathrm{mg} / \mathrm{mL}, 5 \mu \mathrm{L}, 50 \mu \mathrm{g})$. After $30 \mathrm{~min}$, trypsin $(1 \mu \mathrm{L}, 500 \mathrm{ng})$ solution in $25 \mathrm{mM}$ ammonium bicarbonate $(0.5 \mathrm{mg} / \mathrm{mL})$ was added the protein which was digested at $37^{\circ} \mathrm{C}$ overnight.

\section{Endopeptidase GluC digestion}

The proteins were dissolved in $25 \mathrm{mM}$ ammonium phosphate $\mathrm{pH} 7.5(1 \mathrm{mg} / \mathrm{mL})$. The protein solution $(5 \mu \mathrm{L}$, $5 \mu \mathrm{g}$ ) was mixed with DTT $(5 \mathrm{mg} / \mathrm{mL}, 1 \mu \mathrm{L}, 5 \mu \mathrm{g}$ ) and iodoacetamide $(10 \mathrm{mg} / \mathrm{mL}, 5 \mu \mathrm{L}, 50 \mu \mathrm{g})$. After $30 \mathrm{~min}$, endopeptidase GluC ( $1 \mu \mathrm{L}, 500 \mathrm{ng})$ solution in $25 \mathrm{mM}$ ammonium phosphate $(0.5 \mathrm{mg} / \mathrm{mL})$ was added on the above solution and was kept at room temperature overnight.

The digested protein solutions were directly spotted on a MALDI plate and mixed with the matrix ( $\alpha$-cyano4-hydroxycinnamic acid or 2, 5-dihydroxybenzoic acid) before analysis. 
1) Proteomic analysis of SUMO-2/3 dimer 16

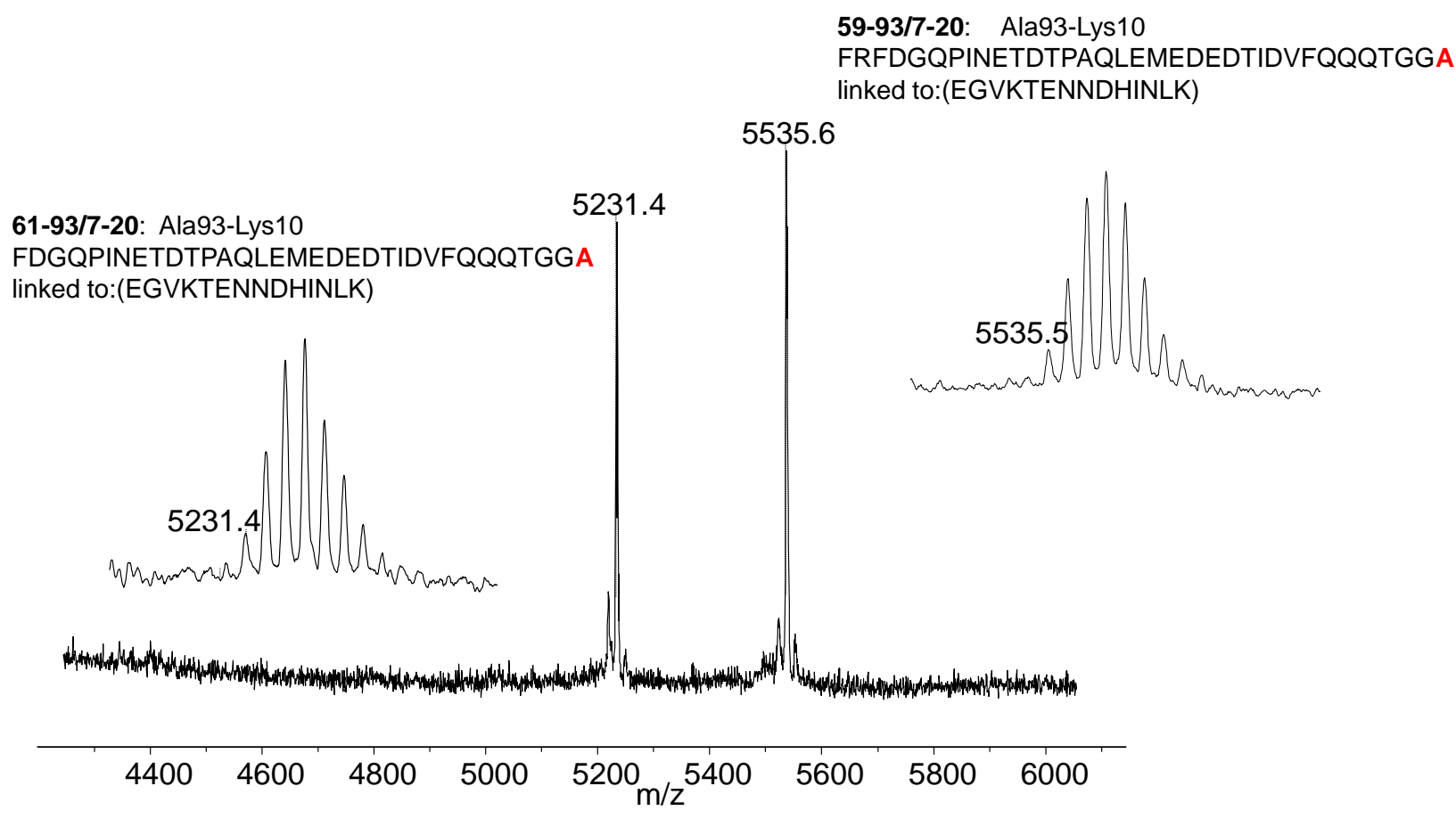

Figure S 16. MALDI-TOF spectrum of the fragments generated after reduction, alkylation and trypsin cleavage of SUMO-2/3 dimer 16 
Internal cysteine state

GSVVQFKIKRHTPLSKLMKAYCE $\left(1{ }^{*}\right.$ Carbamidomethyl(C)

Theoretical monoisotopic molecular weight

$[\mathrm{M}+\mathrm{H}]^{+}=2720.47$

GSVVQFKIKRHTPLSKLMKAYAE

Theoretical monoisotopic molecular weight

$[\mathrm{M}+\mathrm{H}]^{+}=2631.48$

2720.6

2631.6

\begin{tabular}{lllllllll}
\hline 0 & 2550 & 2600 & 2650 & $\mathrm{~m} / \mathrm{z}$ & 2700 & 2750 & 2800 & 2850
\end{tabular}

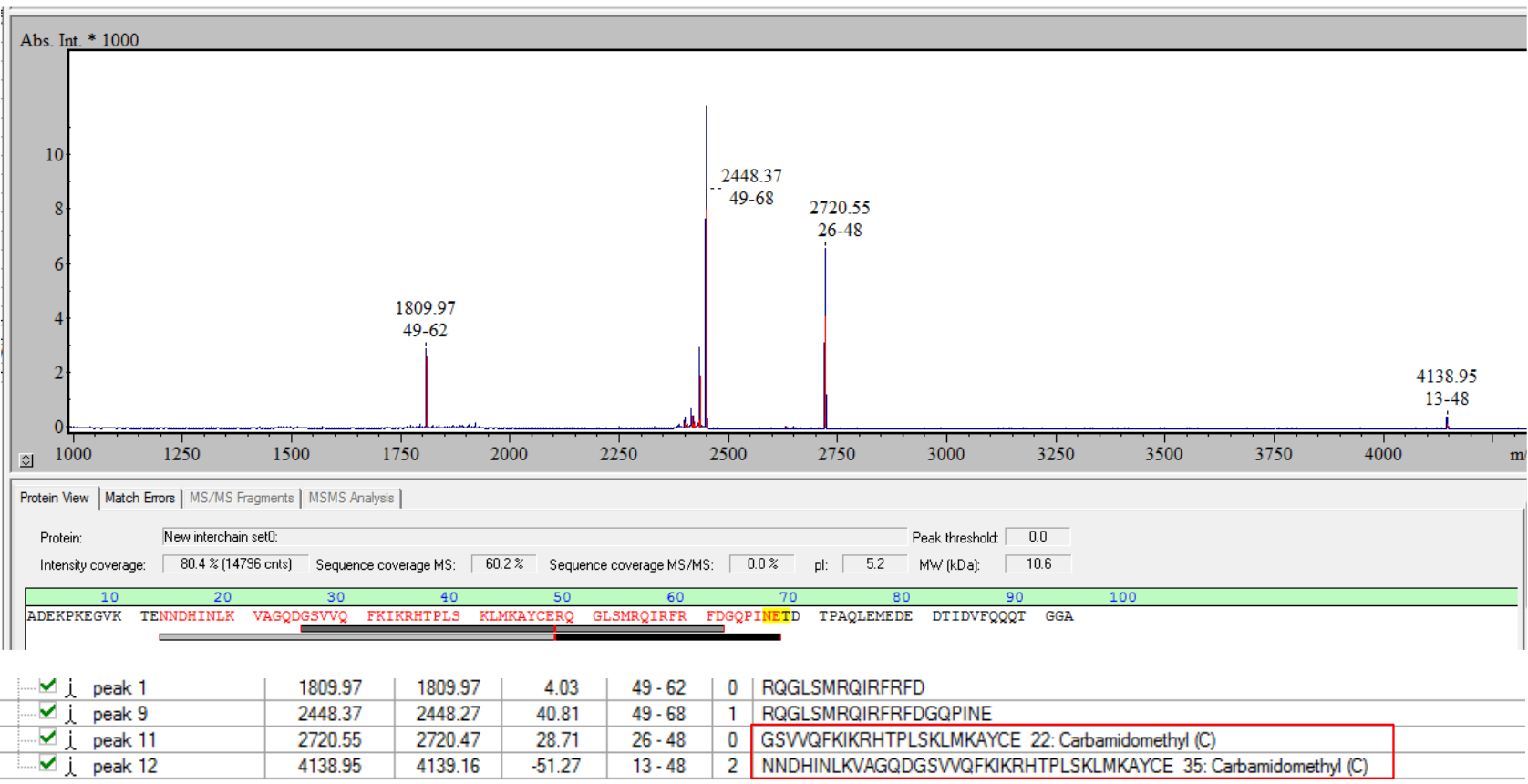

Figure S 17. MALDI-TOF spectrum of the fragments generated after reduction, alkylation and endopeptidase GluC cleavage of SUMO-2/3 dimer 16. 
2) Proteomic analysis of SUMO-2/3 dimer 17

60-92/7-19: Ala92-Lys10

FDGQPINETDTPAQLEMEDEDTIDVFQQQTGGA

linked to:(EGVKTENDHINLK)

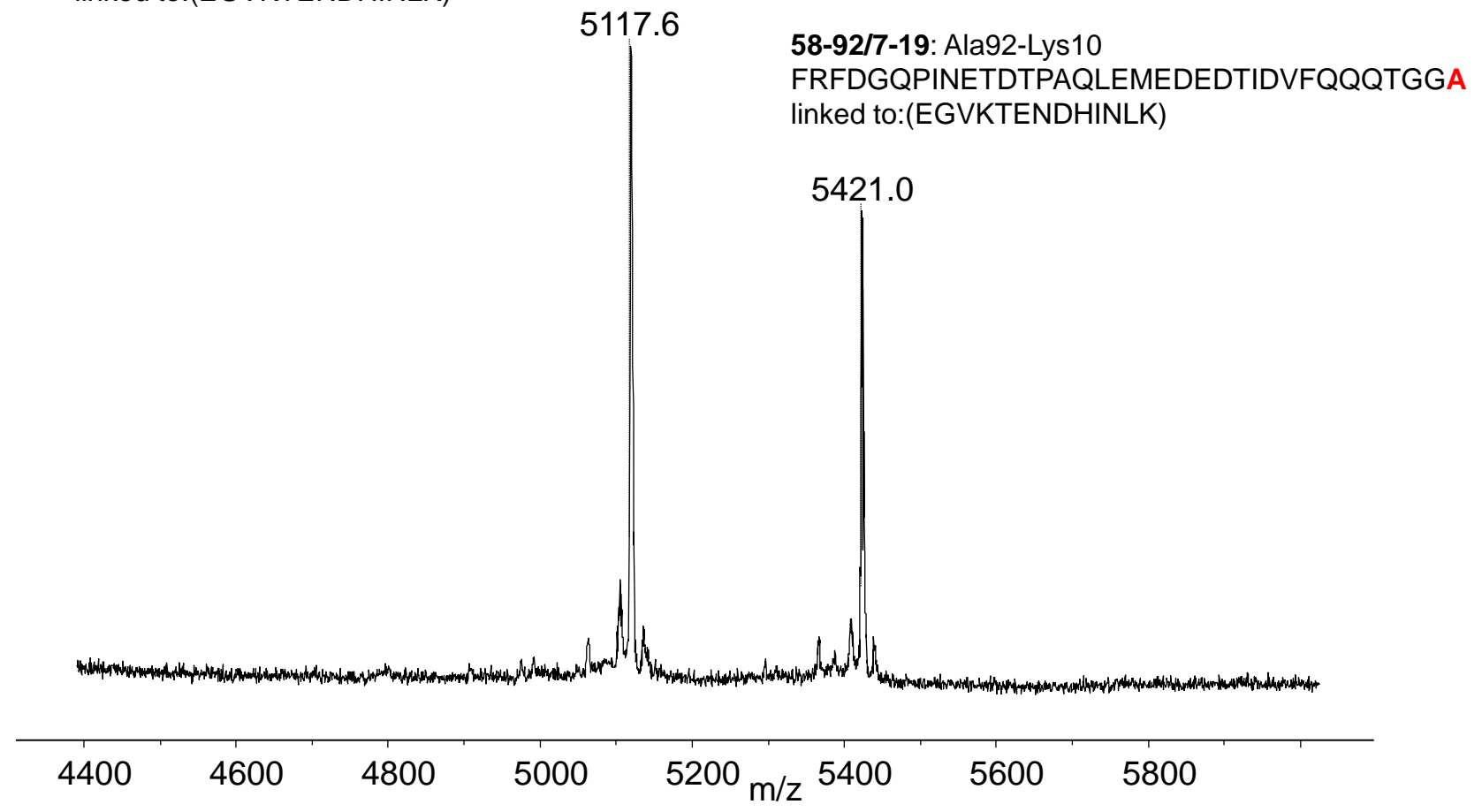

Figure S 18. MALDI-TOF spectrum of the fragments generated after reduction, alkylation and trypsin cleavage of SUMO-2/3 dimer 17 
Internal cysteine state

GSVVQFKIKRHTPLSKLMKAYCE $\left(1^{*}\right.$ Carbamidomethyl(C)

Theoretical monoisotopic molecular weight

$[\mathrm{M}+\mathrm{H}]^{+}=2720.47$

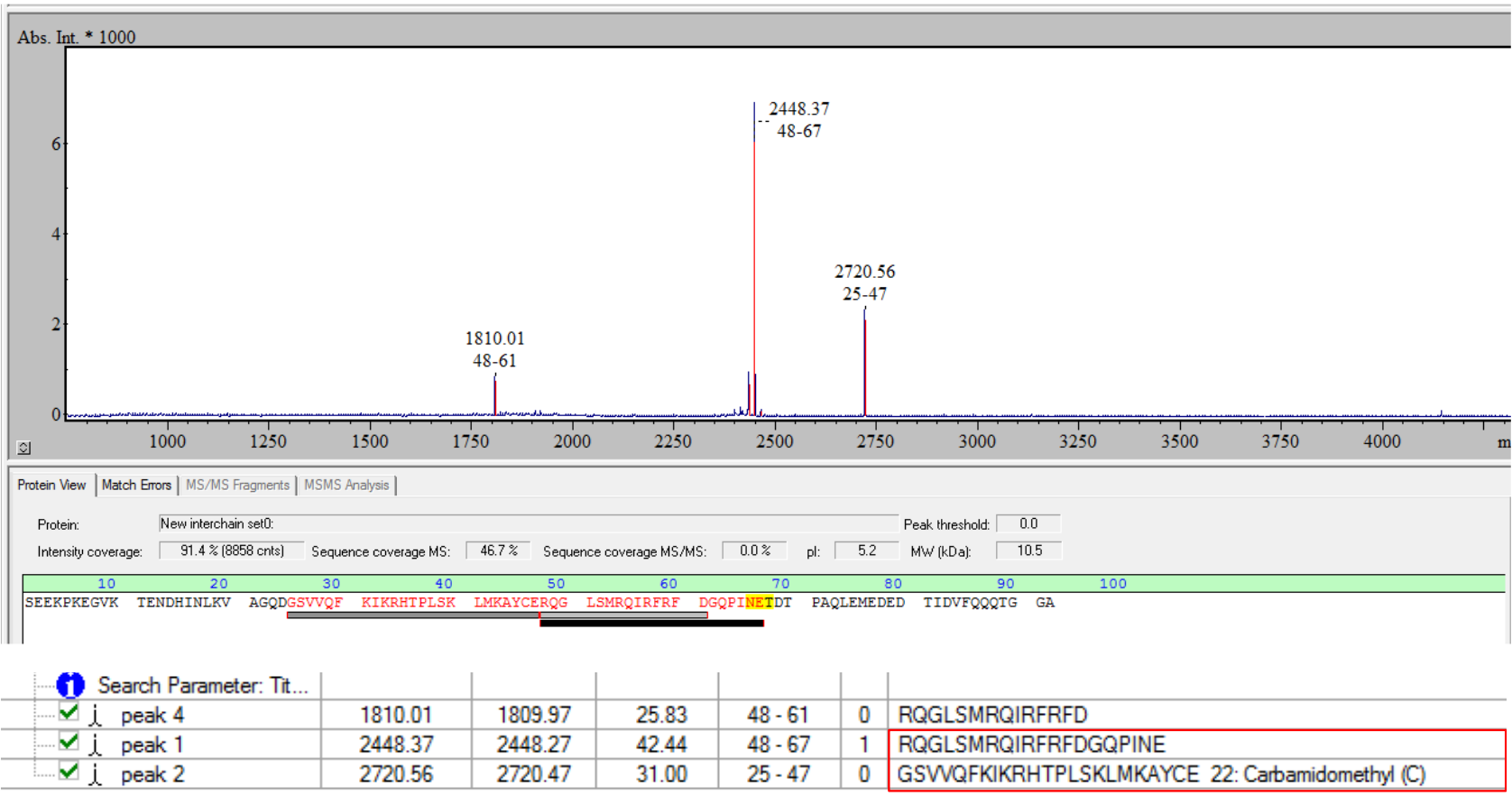

Figure S 19. MALDI-TOF spectrum of the fragments generated after reduction, alkylation and endopeptidase GluC cleavage of SUMO-2/3 dimer 17.

3) Proteomic analysis of SUMO-2/3 dimer 18 
GSVVQFKIKRHTPLSKLMKAYCE $\left(1{ }^{*}\right.$ Carbamidomethyl(C)

Theoretical monoisotopic molecular weight

$[\mathrm{M}+\mathrm{H}]^{+}=2720.47$

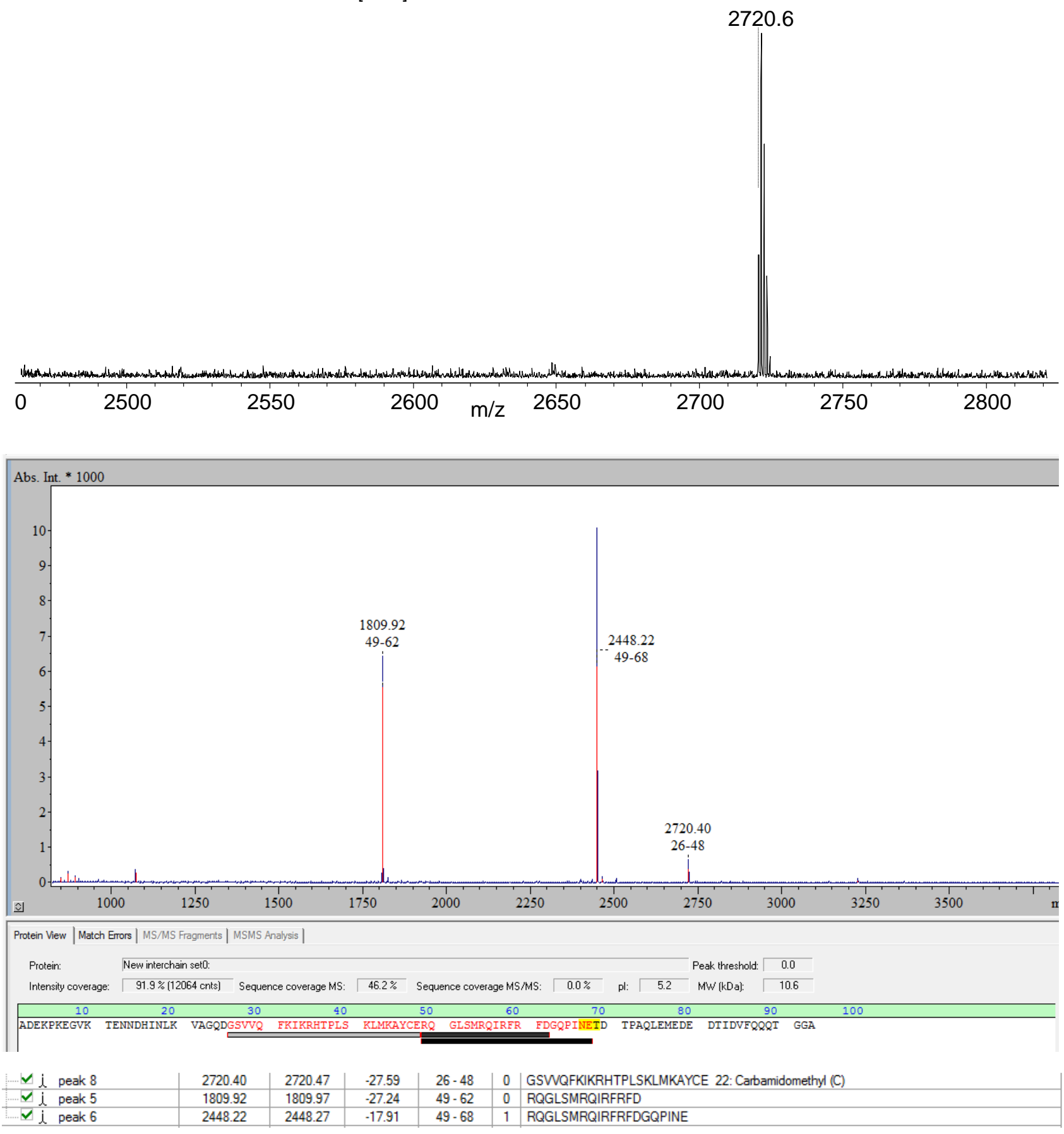

Figure S 20. MALDI-TOF spectrum of the fragments generated after reduction, alkylation and endopeptidase GluC cleavage of SUMO-2/3 dimer 18. 
4) Proteomic analysis of SUMO-2/3 dimer 19

58-92/7-20: Ala92-Lys10

FRFDGQPINETDTPAQLEMEDEDTIDVFQQQTGGA

linked to:(EGVKTENNDHINLK)

60-92/7-20: Ala92-Lys10

FDGQPINETDTPAQLEMEDEDTIDVFQQQTGGA

linked to:(EGVKTENNDHINLK)

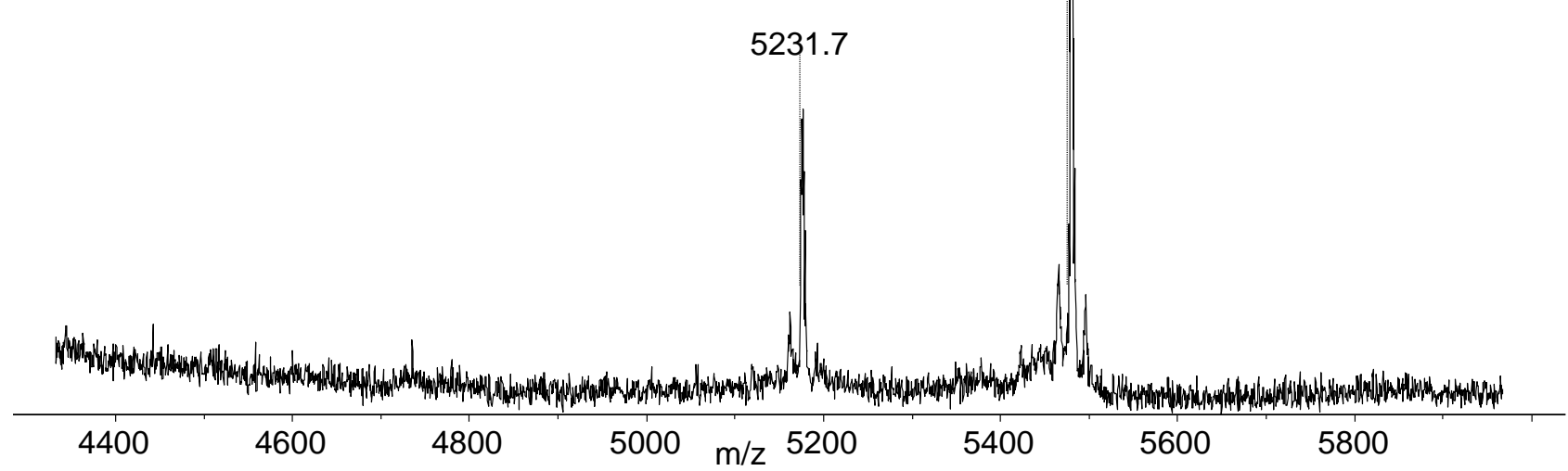

Figure S 21. MALDI-TOF spectrum of the fragments generated after reduction, alkylation and trypsin cleavage of SUMO-2/3 dimer 19 
Internal cysteine state

GSVVQFKIKRHTPLSKLMKAYCE $\left(1{ }^{*}\right.$ Carbamidomethyl(C)

Theoretical monoisotopic molecular weight

$[\mathrm{M}+\mathrm{H}]^{+}=2720.47$
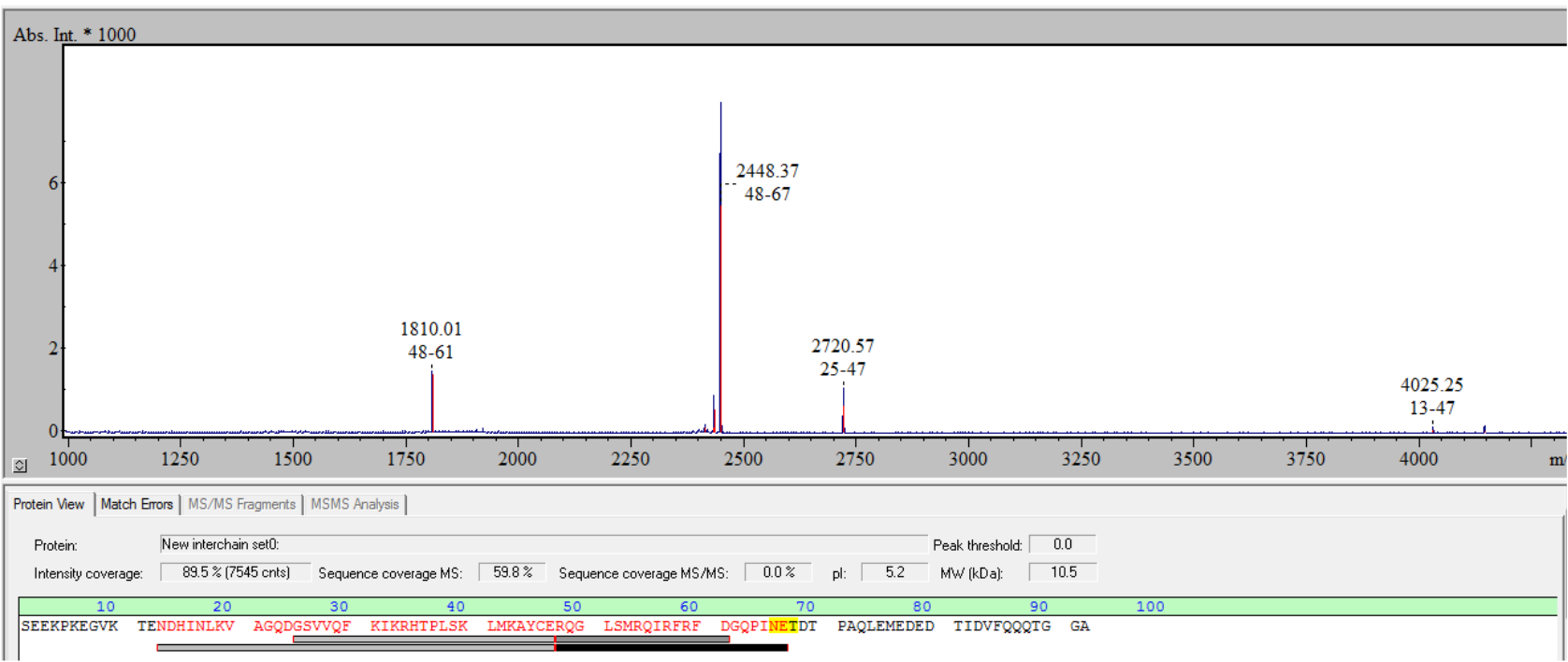

\begin{tabular}{|c|c|c|c|c|c|c|}
\hline $\bar{V}$ i peak 1 & 1810.01 & 1809.97 & 24.77 & $48-61$ & 0 & RQGLSMRQIRFRFD \\
\hline$\checkmark \hat{i}$ peak 5 & 2448.37 & 2448.27 & 41.04 & $48-67$ & 1 & RQGLSMRQIRFRFDGQPINE \\
\hline$\checkmark \hat{l}$ peak 6 & 2720.57 & 2720.47 & 36.93 & $25-47$ & 0 & GSWQFKIKRHTPLSKLMKAYCE 22: Carbamidomethyl (C) \\
\hline$\checkmark \mathrm{i}$ peak 7 & 4025.25 & 4025.12 & 32.75 & $13-47$ & 2 & NDHINLKVAGQDGSWVGFIKRHTPLSKLMKAYCE 34: Carbamidomethyl (C) \\
\hline
\end{tabular}

Figure S 22. MALDI-TOF spectrum of the fragments generated after reduction, alkylation and endopeptidase GluC cleavage of SUMO-2/3 dimer 19. 
5) Proteomic analysis of SUMO-2/3 dimer 20

SUMO-2/3 is the product of the desulfurization of SUMO-2/3 dimer 13 in denaturing conditions.

Internal cysteine state

GSVVQFKIKRHTPLSKLMKAYAE

Theoretical monoisotopic molecular weight $[\mathrm{M}+\mathrm{H}]^{+}=2631.48$
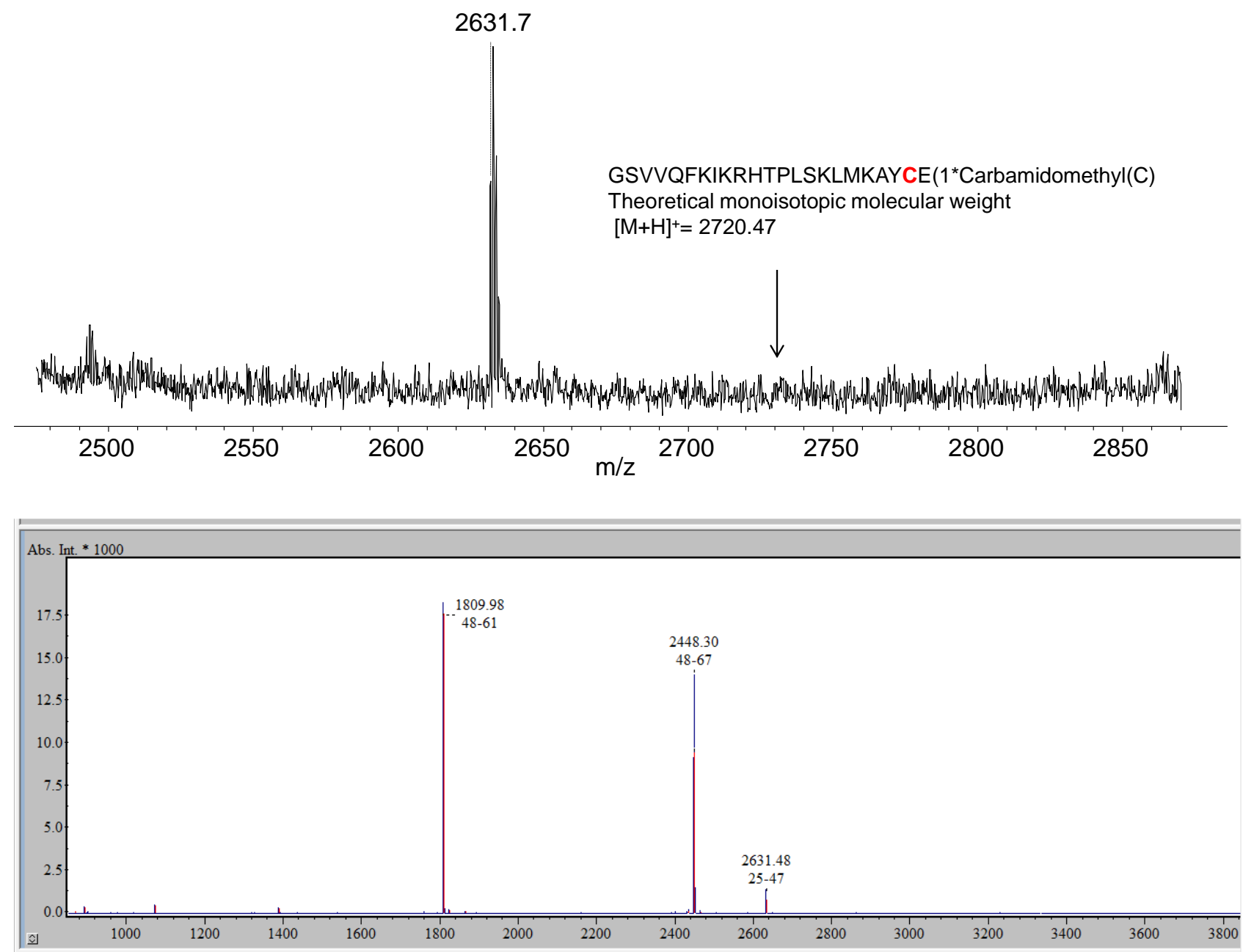

Protein View | Match Errors | MS/MS Fragments | MSMS Analysis |

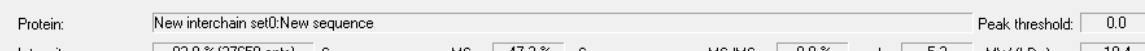

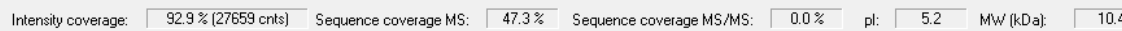

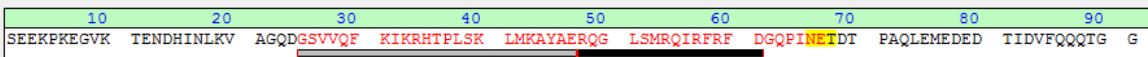

\begin{tabular}{|c|c|c|c|c|c|c|}
\hline$\checkmark \mathrm{i}$ peak 12 & 2631.48 & 2631.48 & 0.93 & $25-47$ & 0 & GSWQFKIKRHTPLSKLMKAYAE \\
\hline$\checkmark i$ peak 6 & 1809.98 & 1809.97 & 8.04 & $48-61$ & 0 & RQGLSMRQIRFRFD \\
\hline 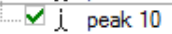 & 2448.30 & 2448.27 & 12.08 & $48-67$ & 1 & RQGLSMRQIRFRFDGQPINE \\
\hline
\end{tabular}

Figure S 23. MALDI-TOF spectrum of the fragments generated after reduction, alkylation and endopeptidase GluC cleavage of SUMO-2/3 dimer 20 


\section{Biophysical and biochemical characterizations}

\section{A. Circular dichroism analysis}

The concentration of different SUMO proteins solubilized in $10 \mathrm{mM}$ sodium phosphate buffer was determined by measuring the absorbance at $280 \mathrm{~nm}$ using a Nanodrop system. The stock solutions of SUMO proteins were diluted with sodium phosphate buffer $(10 \mathrm{mM}, \mathrm{pH} 7.2)$ to a final concentration of 10-20 $\mu \mathrm{M}$ for analysis. The circular dichroism spectra were recorded with a CD6 spectropolarimeter (Jobin-Yvon).

$\mathrm{CD}$ spectra were measured at $25^{\circ} \mathrm{C}$ over the range $185-260 \mathrm{~nm}$ using $0.1 \mathrm{~cm}$ path-length cell and averaging 40 scans. A $2 \mathrm{~nm}$ bandwidth, $1 \mathrm{~nm}$ data pitch were used for spectral acquisition.

The $\alpha$-helical content of the proteins was estimated using the empirical equation of Green- field \& Fasman (Greenfield, N.; Fasman, G. D. Biochemistry 1969, 8, 4108).

\section{B. Cleavage of the SUMO-2/3 dimer 18 with SENP1 or SENP2}

- Monitoring by SDS-PAGE and Coomassie staining (Figure 6)

The enzymatic reactions were carried out at $37^{\circ} \mathrm{C}$ and monitored by SDS-PAGE.

The concentration of the stock solution of the SUMO-2/3 dimer 18 was determined by measuring the absorbance at $280 \mathrm{~nm}$ using a Nanodrop system. The solution was diluted with HEPES buffer $(50 \mathrm{mM}, \mathrm{pH}$ $8) / 100 \mathrm{mM} \mathrm{NaCl}$ to a final concentration of $0.10 \mathrm{mg} / \mathrm{mL}$ (final volume $20 \mu \mathrm{L}$ ). The mixture was kept on ice until addition of SENP1 or SENP2. DTT $(1.54 \mu \mathrm{L}, 10 \mathrm{mg} / \mathrm{mL})$ was added to the protein solutions to give solution A

The concentration of the stock solutions of SENP1 and SENP2 enzymes was $0.5 \mathrm{mg} / \mathrm{mL}$ and 10 units $/ \mu \mathrm{L}$ respectively. The enzymes $(2 \mu \mathrm{L})$ were first diluted with HEPES $(50 \mathrm{mM}, \mathrm{pH} 8.0) / 100 \mathrm{mM} \mathrm{NaCl}$ buffer $(2000$ $\mu \mathrm{L}$ ). Then, $1 \mu \mathrm{L}$ of SENP1 (0.5 ng) or SENP2 (0.02 units) solution was added to the protein solution A. The mixtures were immediately placed at $37^{\circ} \mathrm{C}$. Aliquots of the enzymatic reactions were quenched after 0,2 , 300 min for SENP1 and 0, 30, 300 min for SENP2 by addition $9 \mu$ L of LDS NuPage Sample Buffer (Invitrogen, NP0007) supplemented with $50 \mathrm{mM}$ DTT and $100 \mathrm{mM} \beta$-mercaptoethanol. Samples were heated at $70^{\circ} \mathrm{C}$ for 5 min. Next, $29 \mu \mathrm{L}$ of each sample was loaded into a 4-12\% gradient NuPage Midi Gel (Invitrogen, WG1402A) and eluted in a MES-SDS running buffer (Invitrogen, NP0002) at 150V for $1 \mathrm{~h} 30$.

The gel was fixed and stained in Coomassie solution (water/MeOH/AcOH: 52/40/8 v/v/v, 0.01\% Comassie R250, Sigma B-0149) overnight and then incubated in water/MeOH/AcOH: 72/20/8 v/v/v until obtaining clear background.

\section{- Monitoring by western-blotting}

The Western blotting was performed as proposed by the Sumoylation kit procedure using a 1/1000 antiSUMO2/3 antibody and a 1/30000 anti-rabbit HRP conjugated secondary antibody dilution (Jackson Immunoresearch, \#711-035-152). 


\section{References}

(1) Ollivier, N., Raibaut, L., Blanpain, A., Desmet, R., Dheur, J., Mhidia, R., Boll, E., Drobecq, H., Pira, S. L., and Melnyk, O. (2014) Tidbits for the Synthesis of Bis(2-Sulfanylethyl)Amido (SEA) Polystyrene Resin, SEA Peptides and Peptide Thioesters. J. Pept. Sci. 20, 92-97.

(2) Ollivier, N., Dheur, J., Mhidia, R., Blanpain, A., and Melnyk, O. (2010) Bis(2-Sulfanylethyl)Amino Native Peptide Ligation. Org. Lett. 12, 5238-5241.

(3) Bouchenna, J., Sénéchal, M., Drobecq, D., Stankovic-Valentin, N., Vicogne, J., and Melnyk, O. (2019) The Role of the Conserved SUMO-2/3 Cysteine Residue on Domain Structure Investigated Using Protein Chemical Synthesis. Bioconjugate Chem. 30, 2684-2696.

(4) Stavropoulos, G., Gatos, D., Magafa, V., and Barlos, K. (1996) Preparation of Polymer-Bound TritylHydrazines and their Application in the Solid Phase Synthesis of Partially Protected Peptide Hydrazides. Lett. Pept. Sci. 2, 315-318. 